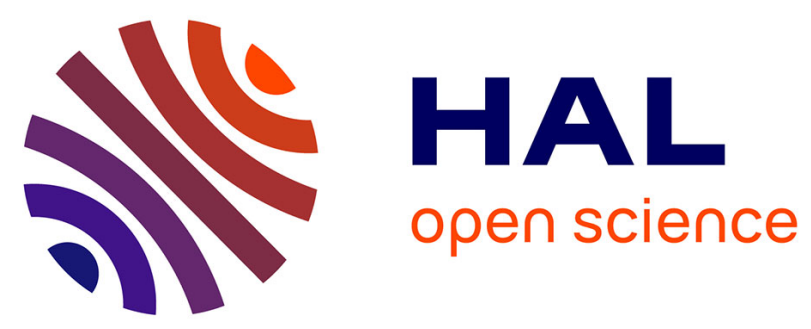

\title{
Stable isotopic composition of anguilliform leptocephali and other food web components from west of the Mascarene Plateau
}

Eric Feunteun, Michael J. Miller, Alexandre Carpentier, Jun Aoyama, Christine Dupuy, Mari Kuroki, M. Pagano, Elodie Réveillac, Daniel Y. Sellos, Shun Watanabe, et al.

\section{To cite this version:}

Eric Feunteun, Michael J. Miller, Alexandre Carpentier, Jun Aoyama, Christine Dupuy, et al.. Stable isotopic composition of anguilliform leptocephali and other food web components from west of the Mascarene Plateau. Progress in Oceanography, 2015, 137 Part A (Part A), pp.69-83. 10.1016/j.pocean.2015.05.024 . hal-01243573

\section{HAL Id: hal-01243573 \\ https://hal.science/hal-01243573}

Submitted on 15 Dec 2015

HAL is a multi-disciplinary open access archive for the deposit and dissemination of scientific research documents, whether they are published or not. The documents may come from teaching and research institutions in France or abroad, or from public or private research centers.
L'archive ouverte pluridisciplinaire HAL, est destinée au dépôt et à la diffusion de documents scientifiques de niveau recherche, publiés ou non, émanant des établissements d'enseignement et de recherche français ou étrangers, des laboratoires publics ou privés. 


\title{
Stable Isotopic Composition of Anguilliform Leptocephali and other Food Web Components from west of the Mascarene Plateau
}

\author{
Eric Feunteun ${ }^{1,2}$, Michael J. Miller ${ }^{3,4}$, Alexandre Carpentier ${ }^{5}$, Jun Aoyama ${ }^{3}$, \\ Christine Dupuy ${ }^{6}$, Mari Kuroki ${ }^{7}$, Marc Pagano ${ }^{8}$, Elodie Réveillac ${ }^{1,2,9}$, Daniel Sellos ${ }^{1,10}$, \\ Shun Watanabe ${ }^{4}$, Katsumi Tsukamoto ${ }^{4}$, Tsuguo Otake ${ }^{7}$ \\ ${ }^{1}$ Museum National d'Histoire Naturelle, UMR 7208 BOREA \\ 38 , rue du port Blanc DINARD, FRANCE \\ ${ }^{2}$ Museum National d'Histoire Naturelle, Station Marine de Dinard \\ 38, rue du port Blanc DINARD, FRANCE \\ ${ }^{3}$ Atmosphere and Ocean Research Institute, The University of Tokyo \\ 5-1-5 Kashiwanoha, Kashiwa, Chiba, 277-8564, JAPAN \\ ${ }^{4}$ Laboratory of Eel Science, Department of Marine Science and Resources, \\ College of Bioresource Sciences, Nihon University \\ 1866 Kameino, Fujisawa-shi, Kanagawa, 252-0880, JAPAN \\ ${ }^{5}$ EA 7316, University of Rennes 1, Bat. 25, Av. du Gl Leclerc \\ 35042 Rennes, FRANCE \\ ${ }^{6}$ LIENSs, UMR 7266 Université de La Rochelle - CNRS, \\ 2 rue Olympe de Gouges, 17000 La Rochelle, FRANCE \\ ${ }^{7}$ Department of Aquatic Bioscience Graduate School of Agricultural and Life Sciences The \\ University of Tokyo, 1-1-1, Yayoi, Bunkyo, Tokyo 113-8657, JAPAN \\ ${ }^{8}$ Mediterranean Institute of Oceanography (MIO), IRD, UMR 235, \\ 13288 Marseille Cedex 09, FRANCE \\ ${ }^{9}$ Agrocampus Ouest, UMR985 ESE Ecologie et Santé des Ecosystèmes, 65 rue de Saint-Brieuc, CS 84215, \\ 35042 Rennes cedex, FRANCE \\ ${ }^{10}$ Museum National d'Histoire Naturelle, Station marine de Concarneau, \\ BP 22529182 Concarneau Cedex, FRANCE
}

Address for correspondence: eric.feunteun@mnhn.fr 


\section{ABSTRACT}

Leptocephali are the poorly-understood transparent larvae of elopomorph fishes that live in the ocean surface layer throughout the world's tropical and subtropical oceans. Their feeding ecology has been difficult to understand because they appear to primarily feed on particulate organic material (POM), which contains few identifiable objects, and there have been few studies on their diets or trophic positions. This study presents the first results on the trophic position of c.a. 50 leptocephali belonging to 7 families of leptocephali that were compared to 30 taxa of other marine animals and to POM samples. To that end, the carbon and nitrogen stable isotope ratios were analyzed on specimens of leptocephali, various taxa of mesozooplankon, cephalopods, fishes, and POM collected west of the Mascarene Plateau in the western Indian Ocean. Nitrogen and carbon isotopic ratio analyses indicated that the 12 taxa of DNA barcoded leptocephali ( $\geq 15$ species) could be separated into 2 groups of species with either higher (Group 1: 9 taxa of 7 families, 25-91 mm) or lower (Group 2: 3 taxa of 2 families, $43-275 \mathrm{~mm}$ ) $\delta^{15} \mathrm{~N}$ ranges. Group 2 exclusively included species that reach much larger sizes of >150-200 mm (Nemichthys and Avocettina, 3 species of Ariosoma-type), whereas Group 1 included Anguilla bicolor bicolor, Serrivomeridae, Muraenidae, Congridae (3 species), Chlopsidae, Ophichthidae (2 species), and Thalassenchelys. Differences in feeding depths, the types of POM ingested by preference or because of different jaw morphology, or the transport of larvae from other regions with different isotopic signatures are possible reasons for the differences between the two groups. The isotopic signatures of 14 taxa of copepods had higher but slightly overlapping $\delta^{15} \mathrm{~N}$ and $\delta^{13} \mathrm{C}$ signatures compared to leptocephali and most crustaceans and other mezozooplankton, cephalopods and mesopelagic fish taxa had even higher values. The $\delta^{15} \mathrm{~N}$ and $\delta{ }^{13} \mathrm{C}$ signatures and composition of POM were variable spatially and with depth and may have been influenced by particulates originating from the shallow banks of the Mascarene Plateau. The two apparent isotopic groups of leptocephali should be examined in relation to their consumption of POM, which can include various proportions of prokaryotes, phytoplankton, protozoans, discarded appendicularian houses and other materials, by conducting further studies in different regions and using a variety of techniques.

\section{Introduction}

The larvae of eels, called leptocephali, are ubiquitously present in the world's tropical and subtropical oceans, but little is known about how they fit into the biological communities of the ocean surface layer where they live because their feeding ecology has only recently begun to be studied. These larvae all have laterally compressed transparent bodies and an unusual physiology (Pfeiler and Govoni, 1993; Bishop and Torres, 1999; Pfeiler, 1999; Bishop et al., 2000). 
Leptocephali are the larvae of eels of the Anguilliformes (including both freshwater and marine eels) and their close relatives of the Elopomorpha (Smith, 1989; Inoue et al., 2004), so more than 800 species of fishes worldwide have this type of larvae (Nelson, 2006). They grow to much larger sizes than most fish larvae (Castle, 1984; Smith, 1989; Miller, 2009), but their behavior and ecology are poorly known because they are difficult to collect due to net avoidance (Miller et al., 2013a).

Moreover, leptocephali are distributed throughout the world's ocean basins from tropical to southern temperate latitudes, which requires large research vessels to reach offshore areas to collect some species. Studies using large midwater trawls have shown they are widely distributed and can be quite abundant in some areas near where spawning occurs for various species (McCleave and Kleckner, 1987; Tsukamoto, 1992; Miller and McCleave, 1994, 2007; Miller et al., 2002).

Their ecology has been so poorly known that until recently, even what they eat was a mystery. Leptocephali in the open ocean mostly live in the upper 100 meters at night and some leptocephali vertically migrate to deeper depths in the upper 300 meters during the day (Castonguay and McCleave, 1987; Otake et al., 1998; Miller, 2009). They are also sometimes collected at the surface in neuston nets (Ross et al., 2007; Miller, 2009), so leptocephali live in the euphotic zone where many different types of possible food particles are present. However, because food items such as small zooplankton had never been seen in their guts, it was initially hypothesized that they did not feed, but instead absorbed dissolved organic carbon (DOC) across the surface of their bodies (Pfeiler, 1986; Hulet and Robins, 1989).

Eventually though, examinations of the gut contents of leptocephali indicated that particulate material including zooplankton fecal pellets and discarded appendicularian (larvacean) houses had been ingested (Otake et al., 1993, Mochioka and Iwamizu, 1996) suggesting that they appear to feed on marine snow containing these types of particulate organic material (POM). Laboratory observations also found that leptocephali can clearly ingest food (Mochioka et al., 1993; Tanaka et al., 2001), so it has become clear that leptocephali do no rely on absorbing DOC for growth.

Exactly what types of POM or other types of food material leptocephali feed on however has remained unclear, due to various types of techniques being applied, each of which provides only parts of the answer to this complex question. The examinations of the gut contents of leptocephali (Otake et al., 1993; Mochioka and Iwamizu, 1996) and photographs of food contents (Miller et al., 2011) in leptocephali collected during the day both support the hypothesis that leptocephali feed primarily during daytime on POM, which includes marine snow, fecal pellets and larvacean houses. Some studies also have begun to use stable carbon and nitrogen isotope analyses of the body contents of a few species leptocephali that indicated they were feeding at a low level within the food web (Otake et al., 1993; Miyazaki et al., 2011), which is consistent with feeding on POM. Another 
study used amino acid nitrogen isotopes to determine the trophic position of small Japanese eel, Anguilla japonica, leptocephali in comparison to other marine organisms, which confirmed the larvae had likely been feeding on marine snow materials (Miller et al., 2013b).

However, it was found that newly hatched anguillid leptocephali would eat rotifers offered to them in the laboratory (Tanaka et al., 1995), and ciliates have recently been reported in the intestines of leptocephali (Govoni, 2010). Other information was obtained from a DNA barcoding study of the gut contents of small European eel, Anguilla anguilla, leptocephali in the Sargasso Sea that detected sequences from a variety of marine organisms including various mesozooplankton such as crustaceans, chaetognaths, polychaetes, and cnidarians (Riemann et al., 2010). It was suggested that gelatinous zooplankton or perhaps their larval stages may be of fundamental dietary importance for those small leptocephali, but how leptocephali may feed on them was not discussed (Riemann et al., 2010). Although this study showed that a diversity of species, or fragments of species were present in the digestive track of Anguilla anguilla leptocephali, it did not examine how these species were ingested and could not evaluate which of these taxa might become digested and assimilated from the intestine.

Because of the sometimes inconsistent information obtained from the few studies on leptocephali, uncertainty remains about the feeding ecology of leptocephali. Marine snow and discarded larvacean houses are widespread and often abundant in the ocean (Alldredge, 1972, 1976; Alldredge and Silver, 1988; Turner, 2002; Pilskaln et al., 2005) and would represent a readily available food source for leptocephali. These types of POM also contain a variety of small organisms or larvae in addition to bacteria (Alldredge and Sliver, 1988; Shanks and Walters, 1997; Kiørboe, 2000), which could explain the findings of the barcoding study by Riemann et al. (2010). It has been suggested that they may target appendicularian houses as a readily available food source (Westerberg, 1990; Mochioka and Iwamizu, 1996), but they also consistently ingest material that does not appear to be larvacean houses (Otake et al., 1993; Miller et al., 2011). However, there are many species of leptocephali with a variety of head and jaw shapes (Fig. S1; Bohlke, 1989; Miller and Tsukamoto, 1994; Miller, 2009), so it is unclear if all species of leptocephali feed on the same types of POM or other materials.

A recent study compared the stable isotope ratios of two species of leptocephali of eels with very different life histories and larval ecologies, which found evidence of differences in some aspects of the feeding ecology (Miyazaki et al., 2011). The larvae of the Japanese eel, Anguilla japonica (a freshwater eel), and those of a shallow water marine eel Ariosoma major (Congridae subfamily Bathymyrinae) showed different isotopic signatures. The reason for the differences were unclear because the Ariosoma larvae were much larger and could have been feeding on different 
types of POM or at different depths; but they also had originated from a completely different part of the subtropical gyre compared to the Anguilla larvae (Miyazaki et al., 2011).

As a next step to understand the unusual feeding ecology of leptocephali, the objective of this study was to examine the stable isotope signatures of a variety of anguilliform leptocephali to determine if there may be differences in their feeding ecologies among taxa or sizes of larvae as reflected in their isotopic signatures. For comparison, the stable isotope values of POM collected at different depths in relation to the thermocline at multiple stations and of a wide range of planktonic organisms from the same survey were determined. Sampling was conducted in 2010 in a tight grid of stations located just to the west of the shallow banks of the Mascarene Plateau in the western Indian Ocean to the east of Madagascar. These analyses provide the first comparative view of the stable isotopic signatures of multiple species of leptocephali in relation to other components of the food web in the surface layer of the ocean.

\section{Materials and methods}

\subsection{Collection of leptocephali and other organisms.}

Sampling to collect leptocephali was conducted during the KH-09-5, Leg 5, cruise of the R/V Hakuho Maru from 29 January to 10 February 2010 to the west of the shallow banks of the Mascarene Plateau (Fig. 1). The banks of the plateau rise up steeply from the ocean bottom to depths as shallow as at least $100 \mathrm{~m}$ (Payet, 2005), with westward flow of the South Equatorial Current passing over and around the banks (Schott and McCreary, 2001; New et al, 2005, 2007; Pous et al., 2010). The grid of sampling stations was set west of the plateau, adjacent to the large Nazareth and Cargados Carajos banks (Fig. 1a). Collections were made at 40 stations using an Isaacs-Kidd Midwater trawl (IKMT) with an $8.7 \mathrm{~m}^{2}$ mouth opening and $0.5 \mathrm{~mm}$ mesh during both day and night. Step tows that sampled 5 different layers were conducted at night (10 min at each depth layer of $120,90,70,50,30 \mathrm{~m}$ ), and oblique tows that fished to a depth of about $500 \mathrm{~m}$ were made during the day. Different trawl deployment methods were used because leptocephali in oceanic waters show a high degree of net avoidance during the daytime (Miller and McCleave, 1994; Miller et al., 2006, 2013a), and some leptocephali exhibit diel vertical migration to deeper depths during the daytime (Castonguay and McCleave, 1987)

The present study will not examine the overall assemblages of leptocephali collected during the sampling survey because this is the focus of a different study (Miller et al., In review), but will focus on the specimens that were selected for the isotope analyses described here. All leptocephali were sorted fresh from the plankton, measured to the nearest $0.1 \mathrm{~mm}$ total length (TL), and identified to the lowest possible taxonomic level on board. The leptocephali were identified to the species 
level in a few cases following the methods of Tabeta and Mochioka (1988), Böhlke (1989) and Miller and Tsukamoto (2004), but because most leptocephali in the Indo-Pacific have not been matched with their adult species (Miller and Tsukamoto, 2004; 2006), the larvae in the present study were separated into species-types.

There were a total of 564 leptocephali of 10 anguilliform families that included about 53 species-types collected during the survey. The family Congridae was most diverse, with 191 leptocephali being collected of about 17 species. Other abundant families were the Serrivomeridae $(\mathrm{N}=106)$ and Nemichthyidae $(\mathrm{N}=142)$. There were 74 leptocephali of 7 species of Ariosoma-type leptocephali collected during the survey. The species identification of these established Ariosomatype larval species-types are not yet known however, so for simplicity these leptocephali will be referred to as "Ariosoma", with the realization that one or more of these species may actually be of a different genus (see Miller et al., 2013c).

Leptocephali were selected for stable isotope analysis to include species with a wide size range of individuals for evaluating possible size-related differences, and also to include at least a few individuals of a range of taxa of 7 families for evaluating possible taxa-related differences. Previous studies only examined 1-2 species of leptocephali, so our goal was to examine a larger number of taxa. Small leptocephali $<20 \mathrm{~mm}$ were excluded because these larvae might not have enough tissue for analysis, and the small leptocephali would also have isotopic signatures that might still be partly influenced by their parents, which were passed on to them through their eggs. This resulted in most leptocephali being in the size range of 30 to $100 \mathrm{~mm}$, with the larger individuals only belonging to Ariosoma, Avocettina, and Nemichthys. For isotope analyses, leptocephali were preserved in 99\% ethanol after they were identified morphologically to the lowest possible taxonomic level onboard during the cruise and held at room temperature until the analysis was performed.

The morphological identifications and the number of possible species within some species types were later evaluated in the laboratory using 655 bp sequences of the mtDNA COI gene (results not shown). The sequences determined were aligned to construct a phylogenetic tree using other sequences of anguilliform eels of each family from the BOLD library and using Elops saurus and Elops hawaiensis sequences as an outgroup because the Elopiformes is the basal taxon of the Elopomorpha (Inoue et al., 2004). This was used to estimate how many species may have been present among the specimens analyzed for their isotopic compositions as shown in Table 1.

Other abundant types of organisms were also sorted fresh out of the plankton and separated into different categories of taxa. These various taxa were randomly selected from stations within the study area. Copepods are abundant in this region (Gallienne et al., 2004, 2005) so they were separated into 14 taxa with various levels of identification. Another general category included the 
invertebrate groups of appendicularians, ascidians, small cephalopods, chaetognaths, decapod larvae, euphausids, isopods, cnidarians, mysids, ostracods, polychaetes, and siphonophores. The fishes consisted of various mesopelagic species that were separated into the categories of hatchetfishes (Sternoptychidae), Myctophididae, small Cyclothone (Gonostomatidae), and Vinciguerria (Phosichthyidae). These various samples that were selected for isotopic analyses were also preserved in $99 \%$ ethanol, which was the safest method of preservation for transportation from Mauritius to France.

\subsection{Hydrographic observations and POM collection.}

Salinity and temperature profiles were measured using a conductivity-temperature-depth (CTD) probe (Sea-Bird SBE 9) to a depth of $500 \mathrm{~m}$ at each station. Concurrently, fluorescence profiles of the water column were measured using a fluorometer attached to the CTD. To collect POM for stable isotopic analysis, water samples were taken at 14 of the stations using 12-L Niskin bottles on the CTD. They were taken at three different depths at each station, which were near the surface $(5 \mathrm{~m})$, maximum of fluorescence at each location $(\sim 80-120 \mathrm{~m})$ and at $100 \mathrm{~m}$. To collect the POM samples, $200 \mathrm{ml}$ seawater samples from the Niskin bottles were passed through a $5 \mathrm{~mm}$ diameter $0.7 \mu \mathrm{m}$ pore size Whatman GF/F filter using a syringe to transfer the water. Filters were previously combusted at $490^{\circ} \mathrm{C}$ for $2 \mathrm{~h}$ to eliminate their organic carbon content. Each filter was dried in the oven at $50^{\circ} \mathrm{C}$ and kept dry in hermetic plastic bags until analysis for their stable isotopic ratios.

\subsection{Flow Cam analyses of water samples}

In parallel, FlowCam (portable system VS IV model, Fluid Imaging Technologies, Inc., Yarmouth, Maine) analyses were made to quantify the detrital matter and the major groups of microplankton (between 63 and $300 \mu \mathrm{m}$ ) such as diatoms and protozoa in the water column. Water samples $(12 \mathrm{~L})$ at each station were gently filtered onto a $63 \mu \mathrm{m}$ mesh nylon net to collect the particles and organisms that were then rinsed and placed in a vial with $25 \mathrm{ml}$ of $0.2 \mu \mathrm{m}$ filtered seawater. Samples were stored in darkness at $4^{\circ} \mathrm{C}$ and were measured within $2 \mathrm{~h}$ after collection. The samples were analyzed by the FlowCam equipped with $300 \mu \mathrm{m}$ flow cell and a $\mathrm{x} 4$ magnification objective. The FlowCam auto-image mode was used for counting live planktonic organisms and detritical particles. The gently stirred samples were introduced from a funnel above the FlowCam and pumped through the FlowCam at a rate of $18 \mathrm{~mL} \mathrm{~h}^{-1}$. The duration of counting was $20 \mathrm{~min}$. and corresponded to from 500 to 1900 particles per sample. The threshold of the scatter detector was 
400, the gain of camera was 2 and the shutter was 8 on the context box of the FlowCam. Before each measurement, the flow cell was cleared of bubbles and washed using filtered water.

The particle classification, concentration, size spectrum of microplankton (diatoms, protozoa) and detrital particles between 63 and $300 \mu \mathrm{m}$ were determined in the FlowCam. We performed the following analyses with the FlowCam-stored data with VisualSpreadsheet software. For most of the cases, alive particles were classified with libraries. Some particles were classified by a taxonomic expert, by looking at the FlowCam images and categorizing them into a group. The abundances of each group were expressed in cells/L.

For autotrophic nanoflagellates (ANF), prokaryotes, picoeukaryotes and cyanobacteria, samples were fixed with prefiltered $(0.02 \mu \mathrm{m})$ buffered formaldehyde ( $2 \%$ final concentration), stored in liquid nitrogen $\left(-162^{\circ} \mathrm{C}\right)$ and analyzed on return to the laboratory. Total cells were enumerated by flow cytometry using the method described by Marie et al. (1997). To enumerate heterotrophic nanoflagellates (HNF), water samples were fixed with glutaraldehyde (1\% final concentration) and stored at $4^{\circ} \mathrm{C}$. In the laboratory, $25 \mathrm{ml}$ of preserved water samples were then stained with DAPI (final concentration, $15 \mathrm{mg} \mathrm{mL}^{-1}$ ) for $15 \mathrm{~min}$, filtered onto black Nuclepore filter (0.8 $\mathrm{mm}$ pore size), stored at $-20^{\circ} \mathrm{C}$, and counted using an epifluorescence microscope (Nikon Eclipse TE200) with UV excitation.

The conversion factors used to convert concentration (cell $\left.\mathrm{L}^{-1}\right)$ into carbon biomass $\left(\mu \mathrm{gC} \mathrm{L}^{-1}\right)$ were: bacteria (14 fgC/cell; Guntersen et al., 2002), cyanobacteria (178 fgC/cell; Charpy and Blanchot, 1998), picoeukaryotes (836 fgC/cell; Verity et al., 1992), nanoflagellates (4700 fg C/cell; Fournier et al., 2012), ciliates (2318 pgC/cell; Putt and Stoecker, 1989), diatoms 225 pg C/cell; Fournier et al., 2012). Because detritus can vary in size and content, its biomass was not estimated.

\subsection{Stable isotope analyses.}

The specimens of leptocephali, other categories of marine organisms and POM used for stable carbon and nitrogen isotope analyses were first washed in distilled water before being deep-freeze lyophilized. Each sample was then individually ground using a ball mill. Their nitrogen and carbon isotopic compositions were then determined using a EA-IRMS isotope-ratio mass spectrometer (Isoprime, Micromass, UK). The carbon and nitrogen isotope ratios were expressed in the delta notation $\delta^{13} \mathrm{C}$ and $\delta^{15} \mathrm{~N}$, where: $\delta \mathrm{X}=\left[\left(\mathrm{R}_{\text {Sample }} / \mathrm{R}_{\text {Reference }}\right)-1\right] \times 1000$, where $\mathrm{X}=\delta^{13} \mathrm{C}$ or $\delta^{15} \mathrm{~N}$ and $\mathrm{R}$ is the ratio ${ }^{13} \mathrm{C}:{ }^{12} \mathrm{C}$ or ${ }^{15} \mathrm{~N}:{ }^{14} \mathrm{~N}$ in the sample and in the reference material. Results are referred to Vienna Pee Dee Belemnite (VPDB) for $\mathrm{C}$ and to atmospheric nitrogen for $\mathrm{N}$ and expressed in units of $\%$ o \pm standard deviation (SD). 
Lipid extraction prior to stable isotope analysis has been suggested by some authors to be useful, because tissue rich in lipids is relatively depleted in $\delta^{13} \mathrm{C}$ (Michener and Lajtha, 2007). We chose not to delipid most of our samples based on the threshold of $\mathrm{C} / \mathrm{N}$ of 3.5 proposed by Post et al. (2007) for aquatic animal samples. Accordingly, only leptocephali larvae were delipidated. They were treated with cyclohexane as described by Chouvelon et al. (2011) in order to remove naturally $\delta^{13} \mathrm{C}$ depleted lipids (De Niro and Epstein, 1977). Cyclohexane is a non-chlorinated solvent with low toxicity that allows for a rapid extraction of total lipids in tissues of marine organisms (Smedes, 1999). It also has the advantage of not impacting $\delta^{15} \mathrm{~N}$ values, as can the more commonly used chloroform-methanol or dichloromethane-methanol mixtures (e.g., Post et al., 2007; Schlechtriem et al., 2003).

As suggested by Kennedy et al. (2002), POM samples were decarbonated using $\mathrm{HCl}$ fumes to get rid of carbonates (as aragonite, dolomite and calcite) in order to obtain $\delta^{13} \mathrm{C}$ values of particular organic carbon (POC) that is assimilated by consumers (Lorrain et al, 2003). As the decarbonatation process alters $\delta^{15} \mathrm{~N}$ values, we used $\delta^{15} \mathrm{~N}$ values from non-decarbonated subsamples of POM.

Statistical tests to compare the isotopic values were conducted using parametric tests ( $t$-test) when the data were normally distributed and had equal variances, and non-parametric tests ( $U$-test; Kruskal-Wallis test followed by post-hoc Dunn's tests for pairwise comparisons) were used when the data did not meet these criteria. In order to evaluate any bias due to different preservation methods between POM (preserved dry) and organisms (preserved in ethanol), we applied a conversion factor as proposed by Chouvelon et al. (2012).

\section{Results}

\subsection{Leptocephalus samples}

The eel larvae specimens used in this study were morphologically identified to the species, genus or subfamily/family level and distinguished into 15 species or genera as shown in Table 1, which consisted of 12 major taxa (larvae of the congrid genus Ariosoma were pooled, and those of the Ophichthidae were pooled). The mtDNA COI analysis verified the morphological identifications and clarified several other things. It showed that a large metamorphosing Ariosoma-type leptocephalus $(275.0 \mathrm{~mm})$, whose morphological characteristics such as lateral pigmentation and gut-type were no longer present to enable identification, was an Ariosoma sp. 7 larva. The mesopelagic eel leptocephali taxa of Avocettina, Nemichthys, and Serrivomeridae were found by the COI analysis to likely contain 2 or 1-2 species or groups, respectively, but for widely distributed species it is not always clear if these represent actual species or just mitochondrial linages (Ma et al., 2008). This indicates that as many as 18 species may have been among the larvae analyzed for their 
stable isotopic ratios. For presentation of the isotopic data, the leptocephali of mesopelagic eel taxa will not be separated according to possibly different species, and the other taxa will be grouped by Ariosoma-type or by family.

Total lengths of the 50 leptocephali used for isotopic analysis ranged from 25-275 mm with the average sizes of the taxa being from $41.8 \mathrm{~mm}$ in Gorgasia to as much as $134.1 \mathrm{~mm}$ in Ariosoma spp. The size range of leptocephali used for analysis matched that of the total sample, except for those $<20 \mathrm{~mm}$ (Fig. S2), which included a wide range of species, with small Serrivomeridae, Nemichthys, and Conger being the most abundant. The majority of the analyzed leptocephali ranged from 30-55 mm, with the larger individuals only belonging to Ariosoma, Avocettina, and Nemichthydae.

\subsection{Isotope ratios of leptocephali}

The stable isotope signatures of the 12 major taxa of leptocephali that were examined (Table 1; Table S1) showed that there were differences in the ranges of both nitrogen and carbon isotopic ratio values among some of the species. Their $\delta^{15} \mathrm{~N}$ values were between about 3 and $10 \%$ and their $\delta^{13} \mathrm{C}$ values were mostly between -21 and -18.5\%o (Fig. 2a). Nemichthys and Avocettina leptocephali showed the widest ranges of both $\delta^{15} \mathrm{~N}$ and $\delta^{13} \mathrm{C}$. All of the other taxa except Ariosoma showed values within a higher and minimally overlapping $\delta^{15} \mathrm{~N}$ range and a lower, but more overlapping $\delta^{13} \mathrm{C}$ range compared to Nemichthys and Avocettina leptocephali. Ariosoma did not overlap with the taxa other than Nemichthys and Avocettina in $\delta^{15} \mathrm{~N}$, but was heavily overlapped in its $\delta^{13} \mathrm{C}$ values. The plot of the mean isotopic values of each major taxa showed that the taxa appeared to represent two groups of species that were Ariosoma, Nemichthys and Avocettina (Group 2) and all the other taxa (Group 1) (Fig. 2b). The two groups were statistically different for both their $\delta^{15} \mathrm{~N}$ (Group 1 , $8.3 \pm 0.6 \%$; Group 2, $5.9 \pm 1.3 \%$ \% $(\mathrm{p}=0.001 ; U$-test $)$ and $\delta^{13} \mathrm{C}($ Group 1, $-20.3 \pm 0.4$; Group 2, $19.7 \pm 0.6)(\mathrm{p}=0.001 ; t$-test $)$ isotopic values. The differences between groups 1 and 2 were not caused by the larvae being collected at different stations, because specimens of both groups were obtained from many of the same 14 stations spread across the study area.

Some variability in isotopic values with size was observed, especially for the Group 2 species that included larger specimens from 100 to $275 \mathrm{~mm}$ (Fig. 3). Although the sample sizes of most taxa were not large enough to be certain about the validity of the apparent trends, the $\delta^{15} \mathrm{~N}$ values showed a possible tendency to decrease in both Nemichthys and Avocettina (Fig. 4b,c). The $\delta^{13} \mathrm{C}$ values of Nemichthys and Ariosoma also tended to decrease with size, but Avocettina suggested an increase in $\delta^{13} \mathrm{C}$ with size (Fig. 5a-c). Conger leptocephali also appeared to have slightly increasing $\delta^{13} \mathrm{C}$ values with length (Fig.5e). The other taxa of leptocephali only had specimens that were all within about a 
$50 \mathrm{~mm}$ or less range in size and did not show any clear trend in isotopic ratios at different sizes (Fig. 4,5). However, none of the $\delta^{15} \mathrm{~N}$ and $\delta^{13} \mathrm{C}$ values of the taxa or groups of species were significantly correlated with length $(\mathrm{p}=0.7-0.89$, Pearson Correlation Test) except for Ariosoma (Fig. 5(a), p = 0.008 ) and Conger for $\delta^{13} \mathrm{C}($ Fig. 5(e), $\mathrm{p}=0.02)$.

\subsection{Isotope ratios of copepods.}

As the samples were collected using an IKMT with $0.5 \mathrm{~mm}$ mesh, all the specimens were larger than about $0.5 \mathrm{~mm}$. A total of 14 copepod taxa were identified among the samples. Their isotope analyses showed average $\delta^{15} \mathrm{~N}$ values that ranged from $7.6 \pm 0.5 \%$ in "Calanidae 1 " to 12.6 $\pm 0.3 \%$ in Gaetanus, with 10 of the other copepod taxa being between about 8 and 10\%o (Fig. 6).

The range of $\delta^{13} \mathrm{C}$ of the copepod taxa ranged from c.a. $-19 \pm 0.3$ in Temora sp and Coricaeus sp. to $-20.6 \pm 0.1$ in Pleuromamma sp. (Table S1).

\subsection{Isotope ratios of mesozooplankton and cephalopods.}

A variety of mezozooplankton and cephalopod taxa were analyzed to help evaluate the isotopic signatures of a range of species with different feeding ecologies (Fig. 7). Lowest $\delta^{15} \mathrm{~N}$ values were observed in a filter-feeding appendicularian (6.2\%o) and in isopods $(6.3 \pm 0.6)$. The highest average $\delta^{15} \mathrm{~N}$ values were for predatory cephalopods $(11.1 \pm 0.6)$ and chaetognaths $(10.4 \pm 1.2)$. The lowest $\delta^{13} \mathrm{C}$ value also occurred in the appendicularian (-20.0) followed by copepods $(-19.7 \pm 0.5)$. The highest average $\delta^{13} \mathrm{C}$ ratios occurred in ostracods $(-17.8 \pm 1.3)$ and polychaetes $(-17.9 \pm 1.6)$, but various taxa also had similar values (Table S1).

\subsection{Mesopelagic fishes.}

The mesopelagic fishes that were examined for their isotopic ratios mostly had high $\delta^{15} \mathrm{~N}$ and a relatively narrow range of $\delta^{13} \mathrm{C}$. The myctophid specimens showed the most variation in $\delta^{15} \mathrm{~N}$ values, with a range of 6.5-12.3\% (Table S1) and the specimens of the other taxa being at levels of $10-12 \%$ (Table $\mathrm{S} 1$ ). The average $\delta^{15} \mathrm{~N}$ value of all the fishes was $10.7 \pm 1.2$, with a total range from 6.5 to 12.8 (Fig. 8). The $\delta^{13} \mathrm{C}$ average was $-18.8 \pm 0.3$ with a range from -19.5 to -17.9 for all individual fish. Hatchetfish (Sternoptychidae) had the highest average $\delta^{15} \mathrm{~N}$, with their individual values ranging from 10.0 to 12.8 and $\delta^{13} \mathrm{C}$ of $-18.7 \pm 0.03$. The three other groups of small Cyclothone, myctophids, and Vinciguerria had average $\delta^{15} \mathrm{~N}$ values ranging from 10.5 to 10.9 , and they had different average $\delta^{13} \mathrm{C}$ values of $-19.3 \pm 0.2,-18.8 \pm 0.3$ and $-18.6 \pm 0.1$, respectively (Table S1). 


\subsection{Isotopic ratios and composition of POM}

The isotope signatures of the POM samples that were collected from different stations and at different depths were highly variable. $\delta^{15} \mathrm{~N}$ ranged from -1.9 to $8.2 \%$ and the average was $4.9 \pm$ 2.5\% . The average $\delta^{13} \mathrm{C}$ was $-26.7 \pm 1.6$, with values ranging from -29.1 to -23.5 . Based on examination of the $\delta^{13} \mathrm{C}$ and $\delta^{15} \mathrm{~N}$ signatures, 5 groups of signatures could be qualitatively distinguished (Fig. 9a). The POM1 group was characterized by very low $\delta^{15} \mathrm{~N}$ values between -0.9 and -0.34 (average: $-0.35 \pm 0.6$ ) and POM2 had values between 1.9 and 3.9 (average: $3.1 \pm 0.8$ ). POM groups 3 to 5 all had $\delta^{15} \mathrm{~N}>4.7$, with averages of $5.8 \pm 0.6,6.1 \pm 1.2$ and $7.3 \pm 0.6$ for POM3, POM4 and POM5, respectively. These three groups were distinguished by their $\delta^{13} \mathrm{C}$ values. POM3 had the lowest average $\delta^{13} \mathrm{C}$ of $-28.3 \pm 0.6$, with values ranging from -29.1 to -27.4 ; followed by POM4 with an average of $-26.3 \pm 0.4$ (-26.8 to -25.5$)$ and POM5, with an average of $-24.2 \pm 0.5$ (24.8 to -23.5$)$ (Fig. 9b).

There was a correlation between the $\delta^{15} \mathrm{~N}$ of POM collected at depths of $5 \mathrm{~m}$ and $100 \mathrm{~m}$ at each station $\left(r^{2}=0.61\right.$; F-test, $\left.p<0.001\right)$, and the average $\delta^{15} \mathrm{~N}$ of POM at $5 \mathrm{~m}$ of all stations was significantly higher than at $100 \mathrm{~m}(t$-test, $\mathrm{p}=0.02)($ Fig. 10b). The average values differed between the two depths by $1.07 \delta^{15} \mathrm{~N} \%$. Similarly $\delta^{13} \mathrm{C}$ at $5 \mathrm{~m}$ was significantly correlated to $\delta^{13} \mathrm{C}$ at $100 \mathrm{~m}$ at each station $\left(\mathrm{r}^{2}=0.90 ; \mathrm{p}<0.001\right)$ and the average difference between the depths being $0.89 \%$ o $(t$ test, $\mathrm{p}<0.001)$ (Fig. 10a).

An interpolation map of POM isotope signatures showed the spatial distribution $\delta^{15} \mathrm{~N}$ and $\delta^{13} \mathrm{C}$ in the areas west of the Mascarene Plateau (Fig. 11). The $\delta^{15} \mathrm{~N}$ values of POM at $5 \mathrm{~m}$ were highest near the Nazareth Bank of the Mascarene Plateau, farther offshore of the Cargados Carajos bank along $58^{\circ} \mathrm{E}$, and again farther to the west. The values at $100 \mathrm{~m}$ remained high all the way to the west along $16^{\circ} \mathrm{S}$ at the latitude of the Cargados Carajos Bank. The $\delta^{13} \mathrm{C}$ of POM at both $5 \mathrm{~m}$ and $100 \mathrm{~m}$ was higher along $58^{\circ} \mathrm{E}$ and decreased to the west. The maps of the average types of POM (types $1-5$ in Fig. 9) at the two depths tended to be highest at the stations where high $\delta^{15} \mathrm{~N}$ values were observed. The highest values (high abundance of POM types 4 or 5 that have both high $\delta^{15} \mathrm{~N}$ and $\delta^{13} \mathrm{C}$ values) were at St. 27 downstream of the Cargados Carajos Bank.

The organismal contents of the POM that was measured by the FlowCam was dominated by prokaryotes that accounted for $70.4 \%$ of the biomass, followed by flagellates $(10.1$ and $7.8 \%$ of biomass in heterotrophic and autotrophic nanoflagellates, respectively), picoeucaryotes (5.9\%), diatoms $(3.0 \%)$, cyanobacteria (1.9\%) and protozoa (0.8\%) (Fig. 12). These ratios were stable 
among depths, except that the proportions of protozoans and diatoms were higher at the depths of maximum fluorescence than at all other depths (not shown).

There was a clear pattern of higher abundance of diatoms, protozoans, and detritus in the eastern side of the sampling grid near the Mascarene Plateau (Fig. 1,13). For example, diatoms were clearly more abundant at St. 38 near the edge of the Cargados Carajos Bank, and protozoans and detritus were most abundant at St. 33 and St. 40, respectively, which were stations over the slope of the plateau. In contrast, both diatoms and protozoans were much less abundant at all the stations where POM was collected in the eastern 3 transects farther offshore.

\subsection{Comparison of isotopic values.}

When the average isotopic ratios of each taxa of leptocephali, copepods, mesozooplankton, cephalopods and small fishes are plotted together it shows that there was some overlap of the leptocephali with a few of the other groups, but that leptocephali had different mean $\delta^{15} \mathrm{~N}$ and $\delta^{13} \mathrm{C}$ signatures than most other taxa. The Group 1 leptocephali ( 9 taxa) overlapped with the individual copepod taxa for both $\delta^{15} \mathrm{~N}$ and $\delta^{13} \mathrm{C}$ (Fig. 14a), but not with the average $\delta^{15} \mathrm{~N}$ value of all the copepods combined (Fig. 14b). Group 2 leptocephali (Ariosoma, Avocettina, Nemichthydae) did not overlap in mean $\delta^{15} \mathrm{~N}$ values with any other taxa, but had similar values as the appendicularian and the isopods. Group 2 did not overlap with any of the mean $\delta^{13} \mathrm{C}$ values of any taxa except appendicularian, isopods, the Group 1 leptocephali and copepods. The mesopelagic fish taxa had higher average $\delta^{15} \mathrm{~N}$ and $\delta^{13} \mathrm{C}$ that showed no overlap with any of the leptocephali taxa, but they overlapped in average $\delta^{15} \mathrm{~N}$ with the cephalopods and chaetognaths, and two of the copepod taxa.

When compared statistically, the 4 categories of organisms and POM combined in Figure 16 were significantly different in their $\delta^{15} \mathrm{~N}$ and $\delta^{13} \mathrm{C}$ values $\left(\mathrm{p}<0.001\right.$; Kruskal-Wallis). For $\delta^{15} \mathrm{~N}$, all groups were different in the pairwise tests ( $\mathrm{p}<0.05$; Dunn's test) except for between copepods and mesozooplankton (including cephalopods) and between leptocephali and POM. However, when the same test was conducted separating the two groups of leptocephali, the results were the same $(\mathrm{p}<$ 0.001) except Group 1 leptocephali were not significantly different than both copepods and mesozooplankton (likely because of the low values of isopods and the appendicularian), and Group 1 leptocephali were different than POM, but Group 2 leptocephali were not. POM and Group 2 leptocephali were marginally different in a separate 2-sample $t$-test though $(\mathrm{p}=0.046)$. For $\delta^{13} \mathrm{C}$ all groups were different in the pairwise tests ( $\mathrm{p}<0.05$; Dunn's test) except for between mesozooplankton and fish and between copepods and leptocephali. When the two groups of leptocephali were separated, the same differences were found $(\mathrm{p}<0.001)$, including both groups of leptocephali not being different than copepods, except that Group 2 leptocephali were different than 
POM and Group 1 were not. Group 1 leptocephali were clearly different in a separate 2-sample $U$ test though $(\mathrm{p}<0.001)$. The overlapping or higher isotopic values of the copepods and other mezozooplankon indicate that almost none of them could have been important components of the leptocephalus larvae's diet.

As POM were preserved dry, and live taxa preserved in ethanol, we applied a correction factor proposed by Chouvelon et al. (2012) to convert $\delta^{15} \mathrm{~N}\left(\delta^{15} \mathrm{~N}_{\text {correct }}=\delta^{15} \mathrm{~N}-1.23 / 0.92\right)$ and $\delta^{13} \mathrm{C}$ $\left(\delta^{13} \mathrm{C}_{\text {correct }}=\delta^{13} \mathrm{C}-8.8 / 1.35\right)$ so that this factor could be assessed. Applying the conversion factor reduced the average $\delta^{13} \mathrm{C}$ and $\delta^{15} \mathrm{~N}$ values of leptocephali by $0.9 \%$ and $0.7 \%$, respectively (not shown), but the $\delta^{13} \mathrm{C}$ signatures of POM were markedly different compared to leptocephali and the other groups with or without using the conversion factor, with there being no overlap in $\delta^{13} \mathrm{C}$ values (Fig. 14b). There was a very wide gap in $\delta^{13} \mathrm{C}$ values, and an overlap in $\delta^{15} \mathrm{~N}$ values. This difference between the POM groups and leptocephali ranged from $-2 \%$ to $-6 \% \delta^{13} \mathrm{C}$ depending on the POM5 and Group1 leptocephali and between POM3, POM4 and Group 2 leptocephali. There was an overlap in the $\delta^{15} \mathrm{~N}$ values between POM and Group 2 leptocephali, although POM5 had almost the same value as Ophichthidae leptocephali.

\section{Discussion.}

Our study provided new information about the isotopic signatures of 12 taxa of leptocephali and made comparisons to the signatures of other components of the food web collected west of the Mascarene Plateau. Morphological characteristics and DNA barcoding data indicated that the larvae of 15-18 species of anguilliform eels were examined for isotopic content. These were representative of the range of leptocephali between 20 and $275 \mathrm{~mm}$ in size, but did not include the smallest sizes of larvae. Although the stable isotope signatures of a few species of leptocephali have been reported before directly (Otake et al., 1993; Kimura and Tsukamoto, 2006; Miyazaki et al., 2011) or incidentally (Waite et al., 2007; Ménard et al. 2014), this is the first study to examine the isotopic signatures of many taxa of leptocephali in comparison to other mesozoplankton, cephalopods, fish, and POM components of the food web in a particular oceanic area.

The $\delta^{13} \mathrm{C}$ signatures of the 12 taxa of leptocephali were mostly overlapping, but two moreseparated ranges of $\delta^{15} \mathrm{~N}$ signatures were observed among the 50 leptocephalus specimens that were examined, which included species with higher values (Group 1: 9 taxa) and those with lower values (Group 2: Ariosoma, Avocettina, Nemichthydae) of $\delta^{15} \mathrm{~N}$. A previous study that analyzed the isotopic signatures of the Japanese eel, Anguilla japonica, and Ariosoma leptocephali in relation to POM in the North Equatorial Current (NEC) region of the western North Pacific (WNP) found a very similar separation of about 3\% between the $\delta^{15} \mathrm{~N}$ values of anguillid larvae and the Ariosoma 
larvae (Miyazaki et al., 2011). Group 1 in the present study included 2 specimens of the Indian shortfin eel, Anguilla bicolor bicolor, as well as several species of Ariosoma in Group 2, which suggests there are similar trophic ecologies of these two general types of eel larvae in both regions. Anguilla japonica leptocephali were also examined for their $\delta^{15} \mathrm{~N}$ values in relation to body size and distribution in one area of the NEC (Kimura and Tsukamoto, 2006). Otake et al. (1993) found a high average $\delta^{15} \mathrm{~N}$ value for 6 Conger myriaster leptocephali from nearshore areas of Japan (11\%o), which is similar to the values of the Conger leptocephali in the present study that were within Group 1. Ménard et al. (2014) included 10 unidentified leptocephali (170-260 mm) in their stable isotope study of micronekton from the Mozambique Channel on the other side of Madagascar that had mean $\delta^{15} \mathrm{~N}$ and $\delta^{13} \mathrm{C}$ values of $5.8 \pm 1.5$ and $-20.6 \pm 0.57$, respectively. Considering the size of their leptocephali, these were likely all Group 2 species, and their isotopic signatures directly overlap with our $\delta^{15} \mathrm{~N}$ and $\delta^{13} \mathrm{C}$ values of Nemichthys and Ariosoma. Another study included "eel leptocephali" (mean $\delta^{15} \mathrm{~N}$ of $\sim 6.6, \delta^{13} \mathrm{C}$ of $\sim-22$ ) in their stable isotope analyses of a range of food web components off western Australia, but it did not identify the families of the leptocephali (Waite et al., 2007). The $\delta^{15} \mathrm{~N}$ signatures of POM and therefore the organisms in the food web can vary regionally (Somes et al., 2010), so evaluation of the isotopic signatures of leptocephali among regions must take this and regional variations in $\delta^{13} \mathrm{C}$ into account. This likely explains why the two groups of taxa in this study had higher $\delta^{15} \mathrm{~N}$ values than the corresponding species of Anguilla and Ariosoma in the WNP (Miyazaki et al., 2011) where the $\delta^{15} \mathrm{~N}$ of POM was suggested to be much lower than in the region of our study (Somes et al., 2010).

The differences in $\delta^{15} \mathrm{~N}$ values among taxa of leptocephali within the same region, suggest that there may be some differences in the feeding ecology of leptocephali, but the limited amount of ecological information about leptocephali make it difficult to know what these differences may be. There are at least two possible reasons for these differences in isotopic signatures, as pointed out by Miyazaki et al. (2011), which are that different species of leptocephali may feed on food sources with contrasting isotopic signatures, or some leptocephali could have been transported into the area of capture from other areas with different isotopic signatures. Some marine organisms such as predatory fishes can move widely between different water masses that may have isotopically distinct food webs (Estrada et al., 2005; Ménard et al., 2007; Lorrain et al., 2014), so this could also occur for leptocephali, which have long larval durations (Miller, 2009). This was supported by the finding of different isotopic signatures of POM and Anguilla japonica leptocephali on either side of a salinity front in the WNP (Kimura and Tsukamoto, 2006). Various taxa of leptocephali also have been observed to have different depth distributions (Castonguay and McCleave, 1987; Miller, 2009). Direct observations of gut contents of leptocephali (Otake et al., 1993; Mochioka and Iwamizu, 
1996; Govoni, 2010; Miller et al., 2011) and DNA analyses of the gut contents of Anguilla (Riemann et al., 2010) have all observed various materials or taxa that could have been consumed as POM, so feeding on slightly different types of POM at different depths could contribute to the two groups having different $\delta^{15} \mathrm{~N}$ signatures. The POM in the present study and in previous studies have shown stable isotopic differences with depth (Waite et al., 2007; Miyazaki et al., 2011; Kolasinski et al., 2012), or in different seasons (Lamb and Steward, 2008; Valls et al., 2014). However, the depth distributions of leptocephali during the daylight hours when most feeding may occur (Miller et al., 2011) are not well-known, in part because of higher net avoidance when light is present (Miller et al., 2013a), so it is difficult to evaluate at what depths each taxa of leptocephali may be feeding.

The two groups may also target different types or sizes of POM aggregates or particles within the same area. The smaller-size individuals of Group 2 leptocephali that overlapped in sizes with Group 1 mostly also had lower $\delta^{15} \mathrm{~N}$ (Fig.3), which suggests the larger size of most specimens is not the only reason for their lower $\delta^{15} \mathrm{~N}$ ratios. One possible difference is that the Group 2 Ariosoma, Avocettina and Nemichthys leptocephali appear to have similar shaped heads and jaws, with a prominent vellum in at least Avocettina (Fig. S1h), which is a membrane designed to seal the buccal cavity to facilitate water being pumped into the esophagus (Miller, 2009). At least some species of Muraenidae have a vellum also (Fig. S1c, Miller, 2009), but the vellum of Avocettina is especially prominent as seen in Fig. S1h. This could increase retention of water and small particles contained within the POM particles, compared to some species in Group 1 that may lack, or have a lessprominent vellum. POM contains a wide variety of materials of different origins including phytoplankton exudates, particles that aggregate together and organisms that colonize the aggregates (Alldredge and Silver, 1988; Holloway and Cowen, 1997; Shanks and Walters, 1997; Kiørboe, 2000; Turner, 2002). Therefore it is possible that the two groups of leptocephali could feed on different types or sizes of POM such as at different depths, which may have different compositions. This possibility is supported by the observation of considerable differences at some stations between the $\delta^{15} \mathrm{~N}$ signatures of POM at $5 \mathrm{~m}$ and $100 \mathrm{~m}$, which in some cases reaches as much as $2-3 \%$ o $\delta^{15} \mathrm{~N}$. In addition, small size POM off Western Australia had a lower $\delta^{15} \mathrm{~N}$ signature $(\sim 2.8)$ than larger sizes ( 6.1) (Waite et al., 2007). Another possibility is that some Group 1 leptocephali may be able to particle feed on large protozoans as suggested by Govoni (2010), which might give them slightly higher $\delta^{15} \mathrm{~N}$ signatures, but these types of organisms may also be ingested along with marine snow. How seemingly very different larval jaw structures, such as those of Eurypharnyx pelecanoides and Thalassenchelys (see Miller, 2009) may be related to their feeding ecology is unclear however.

The $\delta^{13} \mathrm{C}$ signatures of the two groups of leptocephali overlapped considerably, but showed some differences. Interestingly, the $\delta^{13} \mathrm{C}$ signatures of small Group 2 leptocephali were more 
different than those of Group 1 than were some of the larger specimens. This may suggest the possibility of physiological differences between the two groups such as what kinds of materials are digested and assimilated. But there may also be differences in the origins of these larvae, since most Group 1 larvae except for Anguilla species are spawned over or near the continental shelves or banks such as those of the Mascarene Plateau where $\delta^{13} \mathrm{C}$ signatures are usually enriched compared to in offshore waters (Hobson, 1999; Chouvelon et al., 2012; Kolasinski et al., 2012). For example, larvae feeding close to the banks during their early growth period may have different signatures than those that originated in oceanic areas with no influence from materials from the banks.

There may also be shifts in the compositions of the diets of leptocephali as they grow larger especially in Group 2 that includes Ariosoma, Nemichthys and Avocettina or some Group 1 species such as Conger, because our data suggested the possibility that gradual shifts may occur in both $\delta^{13} \mathrm{C}$ and $\delta^{15} \mathrm{~N}$ signatures with increasing leptocephalus size. However, contrary to other types of marine organisms, leptocephali would not be expected to show distinct changes in trophic levels with increasing size if they continue to feed on POM as they grow larger.

The comparisons of leptocephalus isotopic signatures to those of other food web components and POM provided a new opportunity to evaluate the trophic ecology of leptocephali in comparison to other taxa of marine organisms in one specific area. Interpretation of potential food web relationships are typically based on mean values of $\delta^{13} \mathrm{C}$ of animals being usually enriched by $1.1 \%$ or less per trophic level within oceanic systems (e.g., France and Peters, 1997; Michener and Lajtha, 2007) and on the $\delta^{15} \mathrm{~N}$ of animals being enriched on average by $3 \%$ compared with their diet (Minagawa and Wada, 1984; Vander Zanden and Rasmussen, 2001; Post, 2002; McCutchan et al., 2003). However, the isotopic fractionation of leptocephali, which have a very different physiology than most other fish (Bishop and Torres, 1999; Pfeiler, 1999) is not known, and the levels of ${ }^{15} \mathrm{~N}$ enrichment can vary among organisms (Gannes et al., 1997; Vander Zanden and Rasmussen, 2001; McCutchan et al., 2003).

As expected though, the $\delta^{15} \mathrm{~N}$ signatures of leptocephali were clearly lower than the fish, cephalopods, chaetognaths, and 2 taxa of copepods and they showed some overlap between Group 1 leptocephali species and mesozooplankton and copepods. Consequently, there is strong evidence that leptocephali do not feed on these organisms and that they might belong to a detrital-based trophic network composed of marine snow-related microorganisms including algae, bacteria, ciliates and other organisms. This contrasts with microplankton, mesozooplankton and micronekton that depend on the microphytoplankton-zooplankton trophic network. There was a wide gap between leptocephali and POM values, but at least part of this gap could be due to preservation differences. POM was preserved dry on filters, while leptocephali were preserved in ethanol. A conversion 
factor (Chouvelon et al., 2012), slightly reduced the average $\delta^{13} \mathrm{C}$ and $\delta^{15} \mathrm{~N}$ values of leptocephali, but despite this conversion, the gap remained high suggesting that if leptocephali feed on POM, they only assimilate parts of it or only consume some types of POM. Indeed, our study found clear variability in POM composition. The samples collected to the west of the Mascarene Plateau showed a wide range of $\delta^{15} \mathrm{~N}$ signatures that were mostly lower than leptocephali and the mesozooplankton, cephalopods and fish. These variations were likely influenced by the flow of the SEC that passes over and around the shallow banks of the Mascarene Plateau (New et al., 2005, 2007) that may transport various particulate materials from the banks into the offshore areas. An eddy may also sometimes form downstream of the Cargados Carajos Bank in the area with high $\delta^{13} \mathrm{C}$ and $\delta^{15} \mathrm{~N}$ signatures and high POM abundance (New et al., 2007). Offshore transport of isotopically different POM into the Mozambique Channel by a mesoscale eddy was documented recently (Kolasinski et al., 2012), so similar processes likely occur in the Mascarene Plateau area. Detritus, diatoms, and protozoans were also more abundant in the POM samples closer to the banks. Therefore leptocephali in the present study were likely feeding on POM with a variety of origins and compositions in the area where they were collected or in areas where they were before being transported into the study area.

This may complicate the interpretation of the isotopic signatures of leptocephali in relation to those of POM, but other factors also likely influence this relationship. Differences in magnitude of ${ }^{15} \mathrm{~N}$ enrichment among organisms can occur (Gannes et al., 1997; Vander Zanden and Rasmussen, 2001; McCutchan et al., 2003), and the nitrogen isotope enrichment of juvenile A. japonica muscle tissue in continental waters of Japan compared to its diet were not found to correspond to the typical enrichment values (Kaifu et al., 2013). Differences in physiology (Moeri et al., 2003), water temperature (Bloomfield et al., 2011) and nutrient limitation (Aberle and Malzahn, 2007) may also affect isotopic ratios. We also removed the lipids from our leptocephalus samples to avoid bias due to shifts in the $\delta^{13} \mathrm{C}$ signature that are known to occur (Post et al., 2007), and leptocephali may have a lipid content of $>10 \%$ of dry weight (Donnelly et al., 1995; Padron et al., 1996). However, the lipid extraction, and the preservation of all specimens in ethanol, except for the POM samples as mentioned previously, may have contributed to the gap between the $\delta^{13} \mathrm{C}$ signatures of POM and the leptocephali and other organisms, because both delipidization and ethanol preservation can cause higher $\delta^{13} \mathrm{C}$ values (Post et al. 2007; Ruiz-Cooley et al., 2011). It is also possible that some dissolvable components of POM, such as carbohydrates are lost during the filtration process, which might also contribute to the gap in $\delta^{13} \mathrm{C}$ signatures.

In addition, if leptocephali consume POM, there is no evidence that they digest and assimilate all the material that is consumed, such as the zooplankton fecal pellets present in POM (Turner, 
2002) and leptocephalus gut contents (Otake et al., 1993; Mochioka and Iwamizu, 1996; Miller et al., 2011). Marine snow and discarded appendicularian houses contain wide variety of bacteria, cyanobacteria and other microorganisms such as protozoans (Alldredge and Silver, 1988; Volkman and Tanoue, 2002; Simon et al., 2002), as well as colonizing organisms such as ciliates (; Shanks and Walters, 1997; Kiørboe, 2000) that could be digested and would contribute to their nitrogen isotopic signatures. Marine snow also contains various carbohydrates (Holloway and Cowen, 1997; Skoog et al., 2008). These may primarily originate from bacterial and phytoplankton exudates that become transparent, sticky exopolymer particles (TEP) formed by aggregations of polysaccharides, which help to form marine snow (Alldredge et al., 1993; Passow, 2002; Engel, 2004). POM also contains various lipid compounds (Alldredge, 1979; Wakeham and Lee, 1989). Recent chemical analyses of the contents of POM and DOC in the ocean have provided new information about these compounds in the ocean (Skoog et al., 2008; Kaiser and Benner, 2009; Engel and Händel, 2011) and their likely importance in the aggregation of marine snow (Engel et al., 2004). However, carbohydrates contain no nitrogen, so they will not contribute to the $\delta^{15} \mathrm{~N}$ signatures of leptocephali, although they will contribute to their $\delta^{13} \mathrm{C}$ signatures.

The POM examined in the present study contained both heterotrophic and autotrophic flagellates and picoeukaryotes as well as protozoans. All of these types of materials would likely contribute to the nutrition of leptocephali, since they may be easily digested and assimilated. Leptocephali are also known to ingest discarded appendicularian houses (Mochioka and Iwamizu, 1996; Miller et al., 2011), which are considered to be an important contributor to POM and the diets of some marine animals (Alldredge, 1972, 1976). Appendicularians and their houses are widely distributed and often abundant in many areas of the ocean, with the houses being frequently discarded when their filters get clogged and then they are immediately replaced with a new house (Flood and Deibel, 1998; Sato et al., 2003; Fenaux et al., 1998). Therefore, they also would contain a wide range of small particles in addition to the house, some of which could be digested and assimilated by leptocephali. The study by Riemann et al. (2010) found a variety of DNA sequences in the gut contents of small European eel, Anguilla anguilla, leptocephali in the Sargasso Sea including crustaceans, chaetognaths, polychaetes, and cnidarians, but considering the variety of materials that aggregate into marine snow and POM, their findings were also consistent with those larvae having been feeding on POM.

The present study and the previous studies that have used bulk stable isotopes to begin to evaluate the feeding ecology of leptocephali (Otake et al., 2003 ; Kimura and Tsukamoto, 2006; Miyazaki et al., 2011) or have included a few leptocephali in larger studies (Waite et al., 2007; Ménard et al. 2014) have suggested that leptocephali have a low trophic position that is consistent 
with feeding on POM, but knowledge about the nitrogen isotopic composition of the primary producers in a particular habitat is required to be able to estimate the trophic positions of consumers such as leptocephali (Post, 2002). Therefore, perhaps the best confirmation of a low trophic position of leptocephali was obtained using $\delta^{15} \mathrm{~N}$ of amino acids (glutamic acid and phenylalanine) of small A. japonica leptocephali from the NEC (Miller et al., 2013b). This relatively new method has been used to evaluate the trophic position of organisms by analyzing their nitrogen isotopic compositions of amino acids, which does not require the isotopic composition of the primary producers to be analyzed (McClelland and Montoya, 2002; McClelland et al., 2003; Chikaraishi et al., 2007). An average trophic position of 2.4 (primary consumer) was found for wild A. japonica leptocephali compared to a trophic position of 1 for primary producers (Miller et al., 2013b). This is consistent with the findings of the present study that indicated that leptocephali are obtaining nutrition from organisms at low levels within the food web, such as from the wide variety of microorganisms that were detected in the POM samples, as well as any exudates originating directly from primary producers such as diatoms, which are not reflected in the $\delta^{15} \mathrm{~N}$ signatures. The findings of another recent study examining the lipid class and fatty acid concentrations of leptocephali collected over the northern Australia continental shelf also obtained results consistent with leptocephali that were feeding on marine snow-type materials (Deibel et al., 2012).

POM is typically present in the ocean surface layer often at high abundances (Hebel and Karl, 2001; Turner, 2002; Pilskaln et al., 2005), so it is likely ubiquitously available as a food source of leptocephali. The unique physiology of letocephali (Bishop and Torres, 1999; Pfeiler, 1999), with high water content (Donnelly et al., 1995; Bishop et al., 2000) and low respiration (Pfeiler and Govoni, 1993; Bishop and Torres, 1999) seem to make the leptocephalus feeding strategy of consuming POM possible (Pfeiler, 1999; Miller, 2009). But additional research is needed to clarify many aspects of their biology and feeding ecology, such as what types of POM are consumed by leptocephali, what is assimilated from it and if there are taxa-specific feeding ecologies among different groups of leptocephali. Other techniques such as fatty acid analysis or difficult to obtain behavioral observations may also contribute useful information about the mysterious feeding ecology of leptocephali.

\section{Acknowledgements}

We thank the captain and crew of the R/V Hakuho Maru for their assistance with collecting the leptocephali and other plankton and CTD casts, and we also thank all the other scientists and technicians who assisted with collecting and sorting the plankton onboard the cruise. Stephan Pous kindly provided the base map of the study area. Thomas Trancart kindly plotted Fig. 11. The efforts 
of the JAMSTEC cruise planning team and the AORI cruise support office and their technicians are also greatly appreciated.

\section{References}

Aberle, N., Malzahn, A.M., 2007. Interspecific and nutrient-dependent variations in stable isotope fractionation: experimental studies simulating pelagic multitrophic systems. Oecologia 154, 291-303.

Alldredge, A.L., 1972. Abandoned appendicularian houses, a unique food source in the pelagic environment. Science 177, 885-887.

Alldredge, A.L., 1976. Discarded appendicularian houses as sources of food, surface habitats, and particulate organic matter in planktonic environments. Limnology and Oceanography 21, 1423.

Alldredge, A.L., 1979. The chemical composition of macroscopic aggregates in two neretic seas. Limnology and Oceanography 24, 855-866.

Alldredge, A.L., Silver, M.W., 1988. Characteristics, dynamics and significance of marine snow. Progress in Oceanography 20, 41-82.

Alldredge, A.L., Passow, U., Logan, B.E., 1993. The abundance and significance of a class of large, transparent organic particles in the ocean. Deep-Sea Research I, 40, 1131-1140.

Bishop, R.E., Torres, J.J., 1999. Leptocephalus energetics: metabolism and excretion. Journal of Experimental Biology 202, 2485-2493.

Bishop, R.E., Torres, J.J. and Crabtree, R.E., 2000. Chemical composition and growth indices in leptocephalus larvae. Marine Biology 137, 205-214.

Bloomfield, A.L., Elsdon, T.S., Walther, B.D., Gier, E.J., Gillanders, M., 2009. Temperature and diet affect carbon and nitrogen isotopes of fish muscle: can amino acid nitrogen isotopes explain effects? Journal of Experimental Marine Biology and Ecology 339, 48-59.

Böhlke, E.B. (ed), 1989. Leptocephali. Fishes of the Western North Atlantic. Part 9, Vol. 2. Sears Foundation for Marine Research, New Haven.

Castle, P.H.J. 1984. Notacanthiformes and Anguilliformes: Development, In: Moser H.G., Richards W.J. (eds). Ontogeny and Systematics of Fishes. American Society of Ichthyologists and Herpetologists Special Publication 1.pp. 62-93. American Society of Ichthyologists and Hepetologists, New York.

Castonguay, M., McCleave, J.D., 1987. Vertical distributions, diel and ontogenetic vertical migrations and net avoidance of leptocephali of Anguilla and other common species in the Sargasso Sea. Journal of Plankton Research 9, 195-214.

Charpy, L., Blanchot, J., 1998. Photosynthetic picoplankton in French Polynesian atoll lagoons: 
estimation of taxa contribution to biomass and production by flow cytometry. Marine Ecology Progress Series 162, 57-70.

Chikaraishi, Y., Kashiyama, Y., Ogawa, N.O., Kitazato, H., Ohkouchi, N. 2007. Metabolic control of nitrogen isotope composition of amino acids in macroalgae and gastropods: implications for aquatic food web studies. Marine Ecology Progress Series 342, 85-90.

Chouvelon, T., Spitz, J., Caurant, F., Mèndez-Fernandez, P., Chappuis, A., Laugier, F., Le Goff, E., Bustamante, B. 2012. Revisiting the use of $\delta 15 \mathrm{~N}$ in meso-scale studies of marine food webs by considering spatiotemporal variations in stable isotopic signatures - the case of an open ecosystem: the Bay of Biscay (North-East Atlantic). Progress in Oceanography, 101, 92-105.

Deibel, D., Parrish, C.C., Grønkjaer, P., Munk, P., Nielsen, T.G., 2012. Lipid class and fatty acid content of the leptocephalus larva of tropical eels. Lipids 47, 623-634.

De Niro, M.J., Epstein, S. 1977. Mechanism of carbon isotope fractionation associated with lipid synthesis. Science, 197: 261-263.

Donnelly, J., Torres, J.J., Crabtree, R.E. 1995. Proximate composition and nucleic acid content of premetamorphic leptocephalus larvae of the congrid eel Ariosoma balearicum. Marine Biology $123,851-858$.

Engel, A., 2004. Distribution of transparent exoploymer particles (TEP) in the northeast Atlantic Ocean and their potential significance for aggregation processes. Deep-Sea Research I 51, 8392.

Engel, A., Händel, N., 2011. A novel protocol for determining the concentration and composition of sugars in particulate and in high molecular weight dissolved organic matter (HMW-DOM) in seawater. Marine Chemistry 127, 180-191.

Estrada, J.A., Lutcavage, M., Thorrold, S.R., 2005. Diet and trophic position of Atlantic bluefin tuna (Thunnus thynnus) inferred from stable carbon and nitrogen isotope analysis. Marine Biology $147,37-45$

Fenaux, R., Bone Q., Deibel, D., 1998. Appendicularian distribution and zoogeography. In: Bone Q., Editor, The biology of pelagic tunicates, Oxford University Press, Oxford, pp. 251-264.

Flood, P. R., Deibel, D. 1998. The appendicularian house. In: Bone Q (ed) The biology of pelagic tunicates. Oxford University Press, Oxford, p 105-124.

Fournier, J., Dupuy, C., Bouvy, B., Courrodon-Real, M., Charpy, L., Pouvreau, S., Le Moullac, G., Le Pennec, M., Cochard, J.C., 2012. Pearl oysters Pinctada margaritifera grazing on natural plankton in Ahe atoll lagoon (Tuamotu archipelago, French Polynesia). Marine Pollution Bulletin 65, 490-499

France, R.L., Peters, R.H. 1997. Ecosystem differences in the trophic enrichment of 13C in aquatic 
food webs. Canadian Journal of Fisheries and Aquatic Sciences 54, 1255-1258.

Gallienne, C.P., Conway, D.V.P., Robinson, J., Naya, N., William, J.S., Lynch, T., Meunier, S., 2004. Epipelagic mesozooplankton distribution and abundance over the Mascarene Plateau and Basin, southwestern Indian Ocean. Journal of the Marine Biological Association of the UK, 84, 1-8.

Gallienne, C.P., Smythe-Wright, D., 2005 Epipelagic mesozooplankton dynamics around the Mascarene Plateau and Basin, Southwestern Indian Ocean. Philosophical Transactions of the Royal Society A 363, 191-202.

Gannes, L.Z., O’Brien, D.M., Martínez del Rio, C., 1997. Stable isotopes in animal ecology: assumptions, caveats, and a call for more laboratory experiments. Ecology 78, 1271-1276.

Govoni, J., 2010. Feeding on protists and particulates by the leptocephali of the worm eels Myrophis spp. (Teleostei, Anguilliformes, Ophichthidae), and the potential energy contribution of large aloricate protozoa. Scientia Marina 74, 339-344.

Gundersen, K., Heldal, M., Norland, S., Purdie, D., Knap, A., 2002. Elemental C, N and P cell content of individual bacteria collected at the Bermuda Atlantic Timeseries Study (BATS) site. Limnology and Oceanography 47, 1525-1530.

Hebel, D.V., Karl, D.M., 2001. Seasonal, interannual and decadal variations in particulate matter concentrations and composition in the subtropical North Pacific Ocean. Deep-Sea Research II $48,1669-1695$.

Hobson, K.A., 1999. Tracing origins and migration of wildlife using stable isotopes: a review. Oecologia, 120, 314-326.

Holloway, C.F., Cowen J.P., 1997. Development of a scanning confocal laser microscopic technique to examine the structure and composition of marine snow. Limnology and Oceanography 42, $1340-1352$

Hulet, W.H., Robins, C.R., 1989. The evolutionary significance of the leptocephalus larva. In: Böhlke EB (ed). Fishes of the Western North Atlantic. Leptocephali. Part 9, Vol. 2. Sears Foundation for Marine Research, New Haven. pp. 669-677.

Inoue, J.G., Miya, M., Tsukamoto, K., Nishida, M., 2004. Mitogenomic evidence for the monophyly of elopomorph fishes (Teleostei) and the evolutionary origin of the leptocephalus larva. Molecular Phylogeny and Evolution 32, 274-286.

Kaifu, K., Miyazaki, S., Aoyama, J., Kimura, S., Tsukamoto, K., 2013. Diet of Japanese eels Anguilla japonica in the Kojima Bay-Asahi River system, Japan. Environmental Biology of Fishes 96, 439-446.

Kaiser, K., Benner, R., 2009. Biochemical composition and size distribution of organic matter at the Pacific and Atlantic time-series stations. Marine Chemistry 113, 63-77. 
Kennedy, H., Thomas, D.N., Kattner, G., Haas, C., Diekmann, S. 2002. Particulate organic matter in Antarctic summer sea ice: Concentration and stable isotopic composition. Marine Ecology Progress Series 238, 1-13.

Kimura, S., Tsukamoto, K., 2006. The salinity front in the North Equatorial Current: A landmark for the spawning migration of the Japanese eel (Anguilla japonica) related to the stock recruitment. Deep-Sea Research II 53, 315-325.

Kiørboe, T., 2000. Colonization of marine snow aggregates by invertebrate zooplankton: abundance, scaling, and possible role. Limnol. Oceanogr. 45, 479-484.

Kolasinski, J., Kaehler, S., Jaquemet, S., 2012. Distribution and sources of particulate organic matter in a mesoscale eddy dipole in the Mozambique Channel (southwestern Indian Ocean): insight from C and N stable isotopes. Journal of Marine Systems 96-97, 122-131.

Lamb, K., Steward, P.K., 2008. The carbon and nitrogen isotopic values of particulate organic material from the Florida Keys: a temporal and spatial study. Coral Reefs 27, 351-362.

Lorrain, A., Savoye, N., Chauvaud, L., Paulet, Y.M., Naulet, N. 2003. Decarbonatation and preservation method for the analysis of organic $\mathrm{C}$ and $\mathrm{N}$ contents and stable isotope ratios of low-carbonated suspended particulate material. Analytica Chemica Acta 491, 125-133.

Lorrain, A., Graham, B.S., Popp, B.N., Allain, V., Olson, R.J., Hunt, B.P.V., Potier, M., Fry, B., Galván-Magaña, F., Menkes, C.E.R., Kaehler S., Ménard, F., 2014. Nitrogen isotopic baselines and implications for estimating foraging habitat and trophic position of yellowfin tuna in the Indian and Pacific Oceans. Deep-Sea Research. Online first.

Ma, T., Aoyama, J., Miller, M.J., Minegishi, Y., Inoue, J.G., Tsukamoto, K., 2008. Genetic differentiation in the genus Uroconger in the Indo-Pacific region. Aquatic Biology 2, 29-35.

Marie, D., Partensky, F., Jacquet, S., Vaulot, D., 1997. Enumeration and cell-cycle analysis of natural populations of marine picoplankton by flow cytometry using the nucleicacid stain SYBR Green I. Appl. Environmental Microbiology 63,186-193.

McCleave, J.D., Kleckner, R.C., 1987. Distribution of leptocephali of the catadromous Anguilla species in the western Sargasso Sea in relation to water circulation and migration. Bulletin of Marine Science 41, 789-806.

McClelland, J.W., Montoya, J.P., 2002. Trophic relationships and the nitrogen isotopic composition of amino acids in plankton. Ecology, 83, 2173-2180.

McClelland, J.W., Holl, C.M., Montoya, J.P., 2003. Relating low $\delta^{15} \mathrm{~N}$ values of zooplankton to $\mathrm{N}_{2}$ fixation in the tropical North Atlantic: insights provided by stable isotope ratios of amino acids. Deep Sea Research I, 50, 849-861.

McCutchan, J.H. Jr, Lewis, W.M. Jr, Kendall, C., McGrath, C.C., 2003. Variation in trophic shift for 
stable isotope ratios of carbon, nitrogen, and sulfur. Oikos 102, 378-390.

Ménard, F., Lorrain, A., Potier, M., Marsac, F. 2007. Isotopic evidence of distinct feeding ecologies and movement patterns in two migratory predators (yellow-fin tuna and swordfish) of the western Indian Ocean. Marine Biology 153, 141-152.

Ménard F., Benivary H. D., Bodin, N., Coffineau, N., Le Loc'h, F., Mison, T., Richard, P., Potier, M. 2014. Stable isotope patterns in micronekton from the Mozambique Channel. Deep-Sea Research II 100, 153-163

Michener, R., Lajtha, K. 2007. Stable isotopes in ecology and environmental science. R. Michener and K. Lajtha (eds.). 2nd ed. Blackwell Publishing Ltd.

Miller, M.J., 2009. Ecology of anguilliform leptocephali: remarkable transparent fish larvae of the ocean surface layer. Aqua-BioScience Monographs 2, 1-94.

Miller, M.J., McCleave, J.D., 1994. Species assemblages of leptocephali in the subtropical convergence zone of the Sargasso Sea. Journal of Marine Research 52, 743-772.

Miller, M.J., McCleave, J.D., 2007. Species assemblages of leptocephali in the southwestern Sargasso Sea. Marine Ecology Progress Series 344, 197-212.

Miller, M.J., Tsukamoto, K., 2004. An introduction to leptocephali: Biology and identification. Ocean Research Institute, University of Tokyo, 96 pp.

Miller, M.J., Tsukamoto, K., 2006. Studies on eels and leptocephali in Southeast Asia: A new research frontier. Coastal Marine Science 30: 283-292.

Miller, M.J., Otake, T., Minagawa, G., Inagaki, T., Tsukamoto, K., 2002. Distribution of leptocephali in the Kuroshio Current and East China Sea. Marine Ecology Progress Series 235, 279-238.

Miller, M.J., Aoyama, J., Mochioka, N., Otake, T., Castle, P.H.J., Minagawa, G., Inagaki, T., Tsukamoto, K., 2006. Geographic variation in the assemblages of leptocephali in the western South Pacific. Deep-Sea Research I 53, 776-794.

Miller, M.J., Otake, T., Aoyama, J., Wouthuyzen, S., Suharti, S., Sugeha, H.Y., Tsukamoto, K., 2011. Observations of gut contents of leptocephali in the North Equatorial Current and Tomini Bay, Indonesia. Coastal Marine Science 35, 277-288.

Miller, M.J., Stepputtis, D., Bonhommeau, S., Castonguay, M., Schaber, M., Vobach, M., Hanel, R., 2013a. Comparisons of catches of large leptocephali using an IKMT and a large pelagic trawl in the Sargasso Sea. Marine Biodiversity 43, 493-501.

Miller, M.J., Chikaraishi, Y., Ogawa, N.O., Yamada, Y., Tsukamoto, K., Ohkouchi, N., 2013b. A low trophic position of Japanese eel larvae indicates feeding on marine snow. Biology Letters 9, 20120826. 
Miller, M.J., Yamaguchi, M., Wouthuyzen, S., Aoyama, J., Suharti, S., Ma, T., Yoshinaga, T., Minegishi, Y., Kawakami, T., Tsukamoto, K., 2013c. Ariosoma-type leptocephali (Congridae: Bathymyrinae) in the Mentawai Islands region off western Sumatra, Indonesia. Zoological Studies 52, 26.

Miller, M.J., Feunteun, E., Aoyama, J., Watanabe, S., Kuroki, M., Lecomte-Finiger, R., Minegishi, Y., Robinet, T., Reveillac, E., Gagnaire, P.-A., Berrebi, P., Tsukamoto, K., Otake, T. In review. Biodiversity of leptocephali west of the Mascarene Ridge in the southwestern Indian Ocean. Progress in Oceanography.

Minagawa, M., Wada, E., 1984. Stepwise enrichment of ${ }^{15} \mathrm{~N}$ along food chains: further evidence and the relation between $\delta^{15} \mathrm{~N}$ and animal age. Geochimica et Cosmochimica Acta 48, 1135-1140.

Miyazaki, S., Kim, H.-Y., Zenimoto, K., Kitagawa, T., Miller, M.J., Kimura, S., 2011. Stable isotope analysis of two species of anguilliform leptocephali (Anguilla japonica and Ariosoma major) relative to their feeding depth in the North Equatorial Current region. Marine Biology $158,2555-2564$

Mochioka, N., Iwamizu, M., 1996. Diet of anguillid larvae: leptocephali feed selectively on larvacean houses and fecal pellets. Marine Biology 125, 447-452.

Mochioka, N., Iwamizu, M., Kanda, T., 1993. Leptocephalus eel larvae will feed in aquaria. Environmental Biology of Fishes 36, 381-384.

Moeri, O., Sternberg, L.d.S.L.; Rodicio, L.P., Walsh, P.J., 2003. Direct effects of ambient ammonia on the nitrogen isotope ratios of fish tissues. Journal of Experimental Marine Biology and Ecology 282, 61-66.

Nelson, J.S., 2006. Fishes of the World. 4th edn. John Wiley and Sons, Hoboken, NJ.

New, A.L.,Stansfield, K., Smythe-Wright, D., Smeed, D.A., Evans, A.J., Alderson, S.G., 2005. Physical and biochemical aspects of the flow across the Mascarene Plateau in the Indian Ocean. Philosophical Transactions of the Royal Society A363, 151-168.

New, A.L., Alderson, S.G., Smeed, D.A., Stansfield, K.L., 2007. On the circulation of water masses across the Mascarene Plateau in the South Indian Ocean. Deep-Sea Research Part I 54, 42-74.

Otake, T., Nogami, K., Maruyama, K., 1993. Dissolved and particulate organic matter as possible food sources for eel leptocephali. Marine Ecology Progress Series 92, 27-34.

Otake, T., Inagaki, T., Hasumoto, H., Mochioka, N., Tsukamoto, K., 1998. Diel vertical distribution of Anguilla japonica leptocephali. Ichthyological Research 45, 208-211.

Padrón, D., Lindley, V.A., Pfeiler, E., 1996. Changes in lipid composition during metamorphosis of bonefish (Albula sp.) leptocephali. Lipids 31, 513-519.

Passow, U., 2002. Transparent exopolymer particles (TEP) in aquatic environments. Progress in Oceanography 55, 287-333. 
Payet, R., 2005. Research, assessment and management on the Mascarene Plateau: a large marine ecosystem perspective. Philosophical Transactions of the Royal Society A 363, 295-307.

Pfeiler, E., 1986. Towards an explanation of the developmental strategy in leptocephalus larvae of marine fishes. Environmental Biology of Fishes 15, 3-13.

Pfeiler, E., 1999. Developmental physiology of elopomorph leptocephali. Comparative Biochemistry and Physiology A123, 113-128.

Pfeiler, E, Govoni, JJ. 1993. Metabolic rates in early life history stages of elopomorph fishes. Biological Bulletin 185, 277-283.

Pilskaln. C.H., Villareal. T.A., Dennett. M., Darkangelo-Wood. C., Meadows, G., 2005. High concentrations of marine snow and diatom algal mats in the North Pacific Subtropical Gyre: Implications for carbon and nitrogen cycles in the oligotrophic ocean. Deep-Sea Research I 52, 2315-2332.

Post, D.M., 2002. Using stable isotopes to estimate trophic position: models. Methods and assumptions. Ecology 83, 703-718.

Post, D.M., Arrington, D.A., Layman, C.A., Takimoto, G., Quattrochi, J., Montaña, C.G., 2007. Getting to the fat of the matter: models, methods and assumptions for dealing with lipids in stable isotope analyses. Oecologia 152, 179-189.

Pous, S., Feunteun, E., Ellien, C., 2010. Investigation of tropical eel spawning area in the SouthWestern Indian Ocean: Influence of the oceanic circulation. Progress in Oceanography 86, $396-413$

Putt, M., Stoecker, D.K., 1989. An experimentally determined carbon:volume ratio for marine oligotrichous ciliates from estuarine and coastal waters. Limnology and Oceanography 34, 1097-1103.

Riemann, L., Alfredsson, H., Hansen, M.M., Als, T.D., Nielsen, T.G., Munk P., Aarestrup, K., Maes, G.E., Sparholt, H., Petersen, M.I., Bachler, M., Castonguay, M., 2010. Qualitative assessment of the diet of European eel larvae in the Sargasso Sea resolved by DNA barcoding. Biology Letters 6, 819-822.

Ross, S. W., Casazza, T. L., Quattrini, A. M., Sulak, K. J. 2007. Anguilliform larvae collected off North Carolina. Marine Biology 150, 681-695.

Ruiz-Cooley, R.I., Garcia, K.Y., Hetherington, E.D., 2011. Effects of lipid removal and preservatives on carbon and nitrogen stable isotope ratios of squid tissues: Implications for ecological studies. Journal of Experimental Marine Biology and Ecology 407, 101-107

Sato, R., Tanaka, Y., Ishimaru, T., 2003. Species-specific house productivity of appendicularians. Marine Ecology Progress Series 259, 163-172. 
Schlechtriem, C., Focken, U., Becker, K. 2003. Effect of different lipid extraction methods on $\delta 13 C$ of lipid and lipidfree fractions of fish and different fish feeds. Isotopes and Environmental Health Studies 39, 135-140.

Schott, F.A., McCreary J., 2001. The monsoon circulation of the Indian Ocean. Progress in Oceanography 51, 1-123.

Skoog, A., Alldredge, A., Passow, U., Dunne, J., Murray, J., 2008. Neutral aldoses as source indicators for marine snow. Marine Chemistry 108, 195-206.

Shanks, A.L., Walters, K., 1997. Holoplankton, meroplankton, and meiofauna associated with marine snow. Marine Ecology Progress Series 156, 75-86.

Simon, M., Grossart, H., Schweitzer, B., Ploug, H. 2002. Microbial ecology of organic aggregates in aquatic ecosystems. Aquatic Microbial Ecology 28, 175-211.

Smedes, F. 1999. Determination of total lipid using non-chlorinated solvents. Analyst 124, 17111718.

Smith, D.G. 1989. Introduction to leptocephali. In Fishes of the Western North Atlantic. Böhlke, E. B. (ed.), pp. 657-668, Part 9, Volume 2, Sears Foundation for Marine Research, New Haven.

Somes, C.J., Schmittner, A., Galbraith, E.D., Lehmann, M.F., Altabet, M.A., Montoya, J.P., Letelier, R.M., Mix, A.C., Bourbonnais, A., Eby, M., 2010. Simulating the global distribution of nitrogen isotopes in the ocean. Global Biogeochemical Cycles 24, GB4019.

Tabeta, O., Mochioka, N., 1988. Leptocephali. In An atlas of the early stage fishes in Japan, Okiyama, M. (eds.), pp. 15-64, Tokai University Press, Tokyo.

Tanaka, H., Kagawa, H., Ohta, H., Okuzawa, K., Hirose, K., 1995. The first report of eel larvae ingesting rotifers. Fisheries Science 61, 171-172.

Tanaka, H, Kagawa, H, Ohta, H. 2001. Production of leptocephali of Japanese eel (Anguilla japonica) in captivity. Aquaculture 201, 51-60.

Tsukamoto, K., 1992. Discovery of the spawning area for the Japanese eel. Nature. 356, 789-791.

Turner, J.T., 2002. Zooplankton fecal pellets, marine snow and sinking phytoplankton blooms. Aquatic Microbial Ecology 27, 57-102.

Vander Zanden, M.J., Rasmussen, J.B., 2001. Variation in $\delta^{15} \mathrm{~N}$ and $\delta^{13} \mathrm{C}$ trophic fractionation: implications for aquatic food web studies. Limnology and Oceanography 46, 2061-2066.

Valls, M., Olivar, M.P., Fernández de Puelles, M.L., Molí, B., Bernal, A., Sweeting, C.J. 2014. Trophic structure of mesopelagic fishes in the western Mediterranean based on stable isotopes of carbon and nitrogen. Journal of Marine Systems 138, 160-170. 
Verity, P., Robertson, C., Tronzo, C., Andrews, M., Nelson, J., Sieracki, M., 1992. Relationship between cell volume and the carbon and nitrogen content of marine photosynthetic nanoplankton. Limnology and Oceanography 37, 1434-1446.

Volkman, J.K., Tanoue, E., 2002. Chemical and biological studies of particulate organic matter in the ocean. Journal of Oceanography, 58, 265-279.

Waite, A.M., Muhling, B.A., Holl, C.M., Beckley, L.E., Montoya, J.P., Strzelecki, J., Thompson, P.A., Pesant, S. 2007. Food web structure in two counter-rotating eddies based on $\delta^{15} \mathrm{~N}$ and $\delta$ ${ }^{13} \mathrm{C}$ isotopic analyses. Deep-Sea Research II 54, 1055-1075.

Wakeham, S.G., Lee, C., 1989. Organic geochemistry of particulate matter in the ocean: The role of particles in oceanic sedimentary cycles. Organic Geochemistry 14, 83-96.

Westerberg, H., 1990. A proposal regarding the source of nutrition of leptocephalus larvae. Internationale Revue der gesamten Hydrobiologie und Hydrographie 75, 863-864. 


\section{Table 1}

Number of specimens, taxonomic composition, size (total length: TL), and mean isotopic values of the leptocephali that were used in this study. The number of possible species or species types suggested by the CO1 DNA barcoding are shown in parentheses for some taxa. The larvae are also distinguished according to the general life history types of their juveniles and adults as being catadromous (CT), living on the continental shelf or slope in the marine environment (SH), or living completely pelagic lives mostly in the mesopelagic zone of the ocean (OC). See Table S1 for isotopic values of all the taxa of pelagic animals and POM examined in this study.

\begin{tabular}{llcccc}
\hline Family (LH) & Morphological & N & TL & $\begin{array}{c}\delta^{15} \mathrm{~N} \\
\text { Mean } \pm \text { S.D. }\end{array}$ & $\begin{array}{c}\delta^{13} \mathrm{C} \\
\text { Mean } \pm \text { S.D. }\end{array}$ \\
\hline Anguillidae (CT) & Anguilla bicolor bicolor & 2 & $51.2-54.1$ & $8.6 \pm 1.2$ & $-20.5 \pm 0.03$ \\
Congridae (SH) & Ariosoma sp. & 1 & 118.0 & 5.6 & -19.9 \\
& Ariosoma sp. 6 & 1 & 81.0 & 5.7 & -19.8 \\
& Ariosoma sp. 7 & 3 & $46.2-227.0$ & $5.8 \pm 0.9$ & $-19.9 \pm 0.5$ \\
& Ariosoma sp.*(sp. 7) & 1 & 275.0 & 6.5 & -20.7 \\
& Conger sp. & 6 & $31.0-91.0$ & $8.4 \pm 0.9$ & $-20.5 \pm 0.4$ \\
& Gnathophis & 1 & 70.6 & 9.1 & -20.8 \\
& Gorgasia & 3 & $39.2-44.9$ & $8.2 \pm 0.1$ & $-20.0 \pm 0.5$ \\
Chlopsidae (SH) & Sp. 5 & & & & \\
Muraenidae (SH) & Uropterigiinae & 1 & 55.5 & 8.9 & -20.7 \\
Ophichthidae (SH) & Myrophinae & 1 & $19.5-21.2$ & $7.9 \pm 0.3$ & $-19.8 \pm 0.3$ \\
& Neenchelys & 1 & 27.2 & 7.3 & -19.6 \\
Unknown (?) & Thallassenchelys & 1 & 55.5 & 8.0 & -20.6 \\
Nemichthyidae (OC) & Avocettina (1-2) & 6 & $44.6-203.3$ & $5.9 \pm 1.9$ & $-19.3 \pm 0.9$ \\
& Nemichthys (1-2) & 12 & $43.2-243.4$ & $6.0 \pm 1.3$ & $-19.7 \pm 0.6$ \\
Serrivomeridae (OC) & sp. & 7 & $25.0-62.0$ & $8.4 \pm 0.4$ & $-20.5 \pm 0.2$ \\
\hline
\end{tabular}

* Leptocephalus was metamorphosing. 


\section{Figure Captions}


Fig. 1. Map of the study area showing (a) the 40 IKMT and CTD stations (numbered in right panel) that were sampled during the KH-09-5 survey for leptocephali to the west of the shallow banks

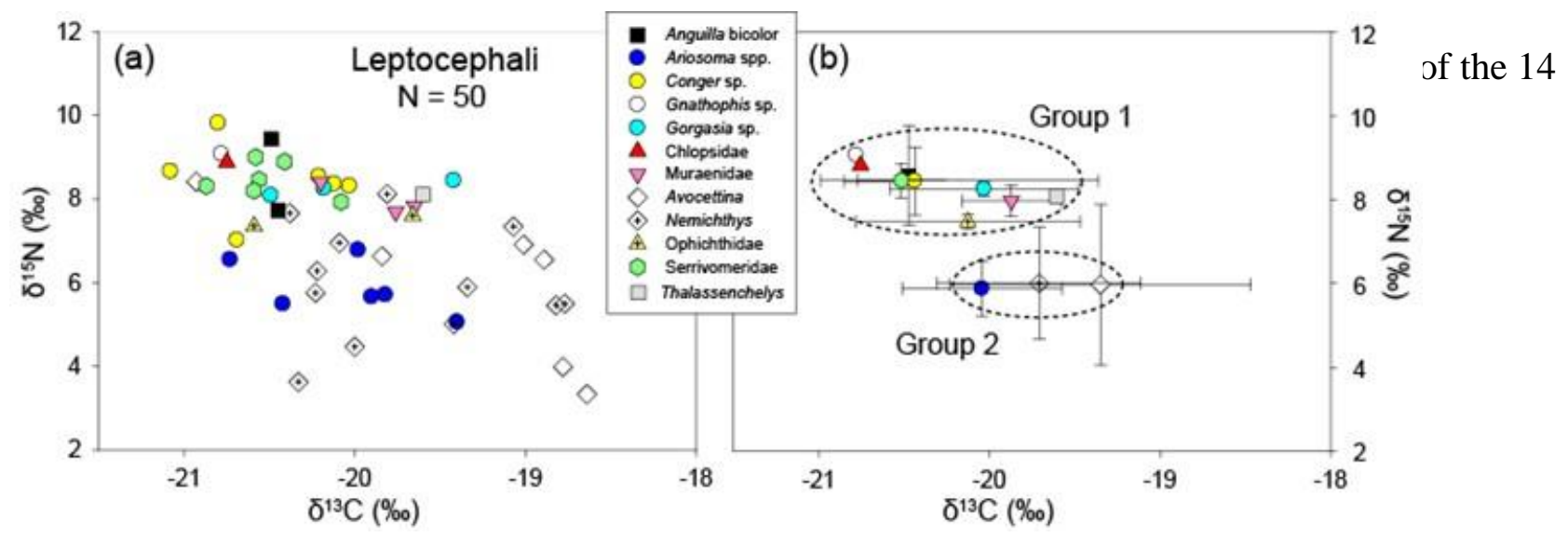

Fig. 2. Isotope ratio values of $\delta^{15} \mathrm{~N}$ and $\delta^{13} \mathrm{C}$ of (a) all specimens of 12 taxa of leptocephali analyzed and (b) the mean values of each taxa with standard deviation bars that were separated into two groups according to their isotopic ratios. 

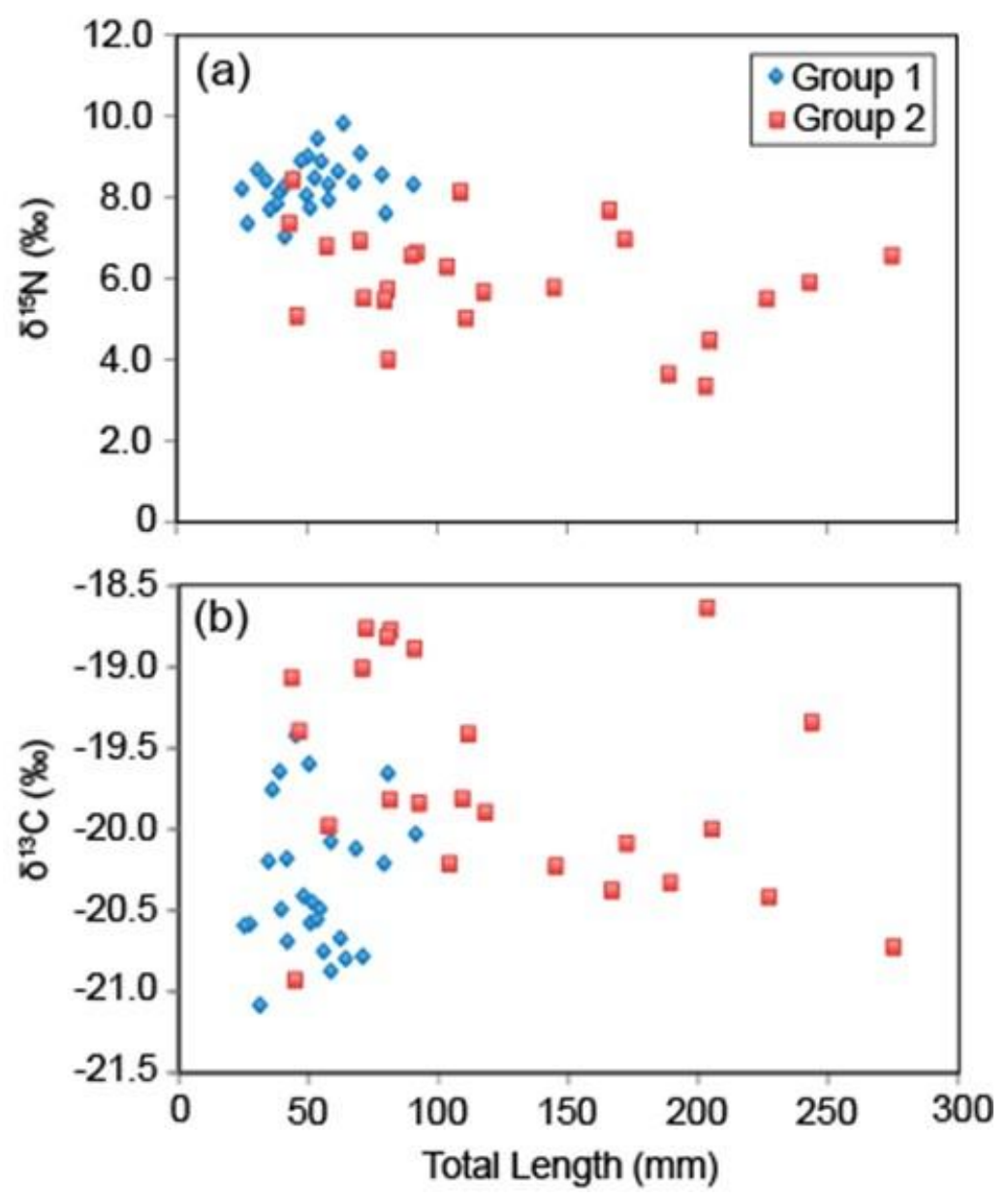

Fig. 3. Plots of (a) $\delta^{15} \mathrm{~N}$ and (b) $\delta^{13} \mathrm{C}$ values of individual leptocephali according to their total length for Group 1 (Nemichthys, Avocettina and Ariosoma) and Group 2 (9 other taxa) that were separated according to their isotopic ratios as shown in Fig. 2. 

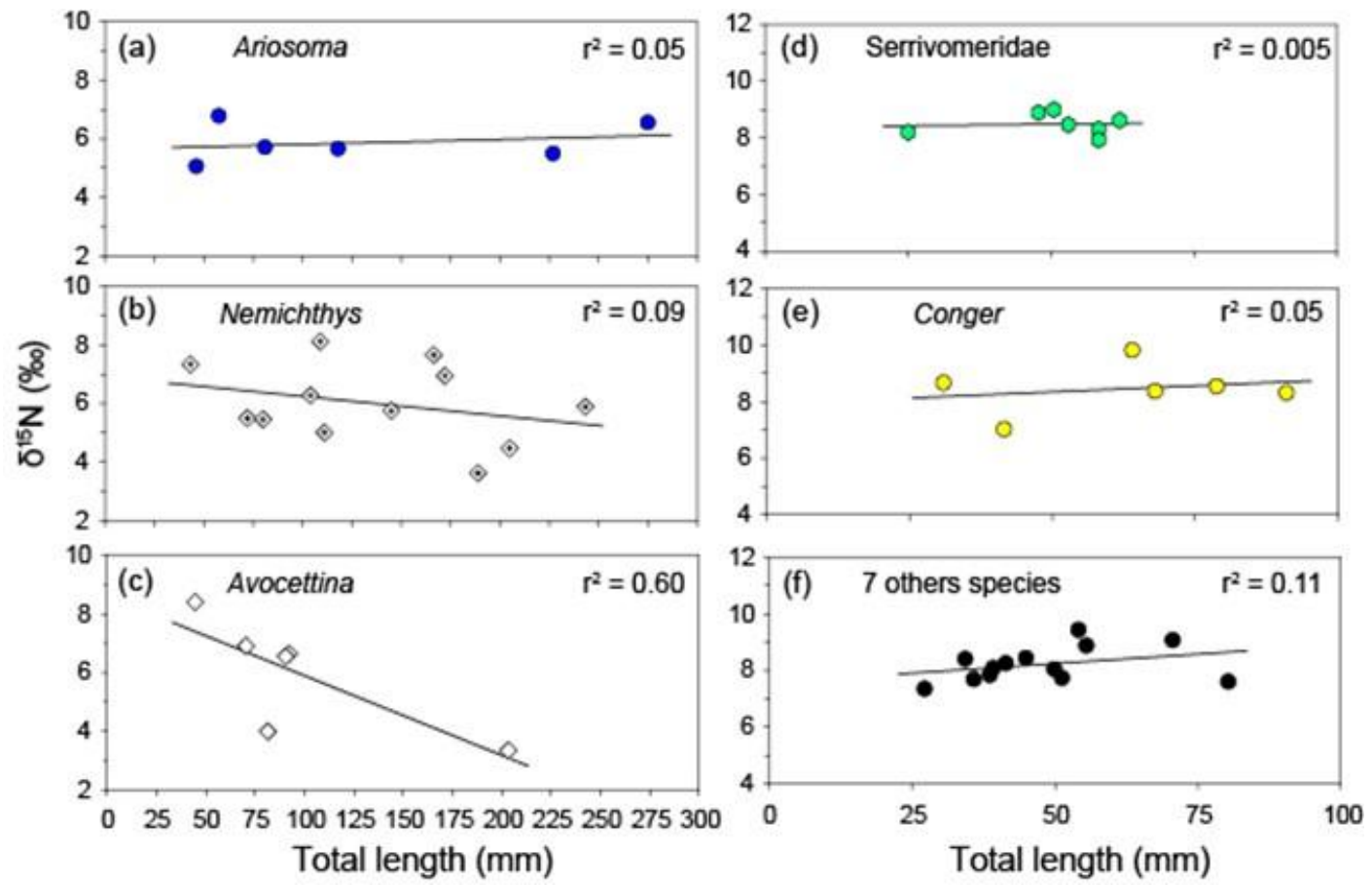

Fig. 4. Plots of $\delta^{15} \mathrm{~N}$ values according to the total length of leptocephali of (a-c) the 3 Group 2 taxa, and (d-f) of the other leptocephali of Group 1. 

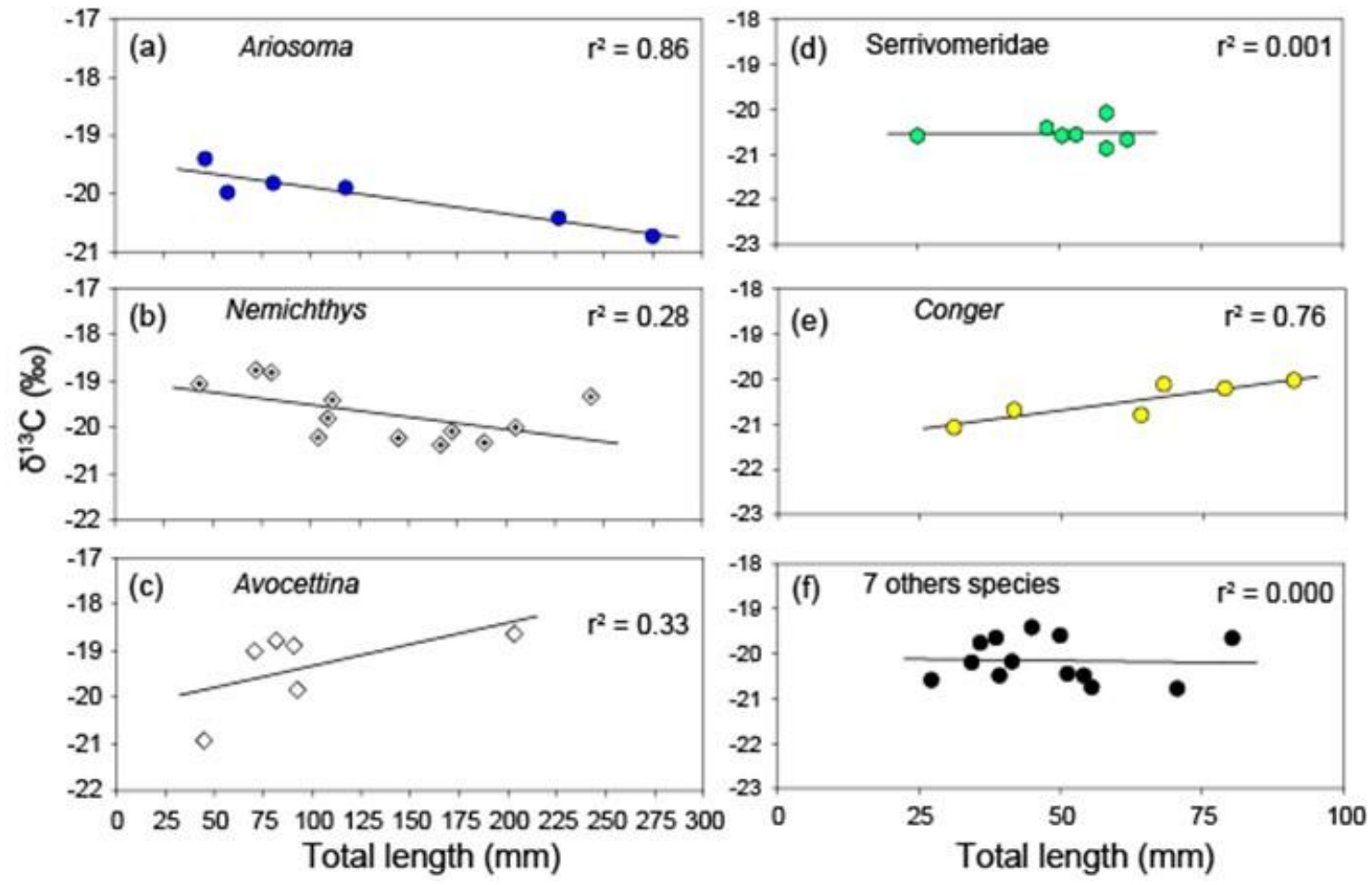

Fig. 5. Plots of $\delta^{13} \mathrm{C}$ values of different sizes of leptocephali of (a-c) the Group 2 taxa, and (d-f) of the other leptocephali of Group 1. 


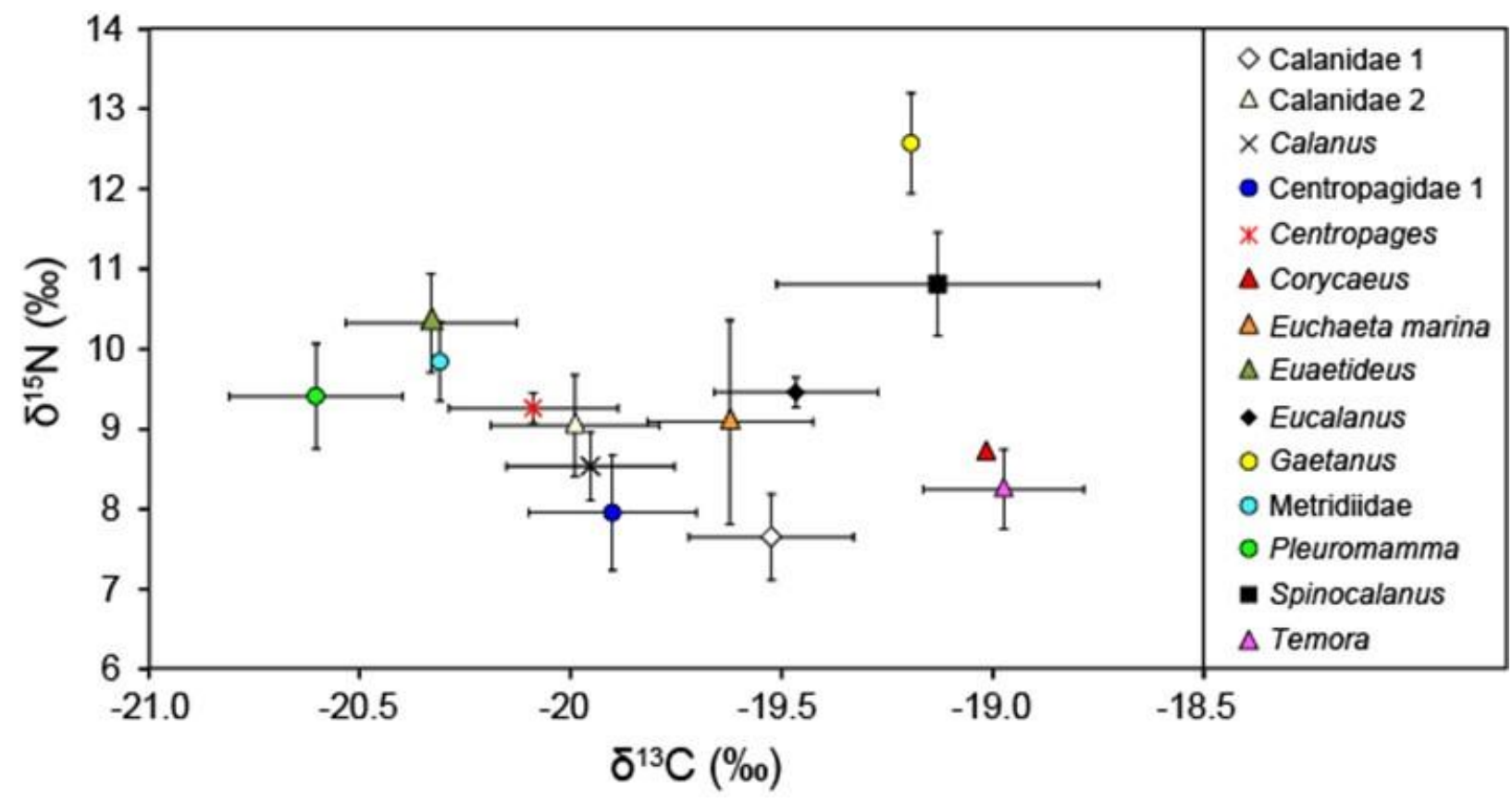

Fig. 6. Plots of the average $\delta^{15} \mathrm{~N}$ and $\delta^{13} \mathrm{C}$ isotope ratio values of 14 taxonomic groupings of copepods (bars show S.D.). 


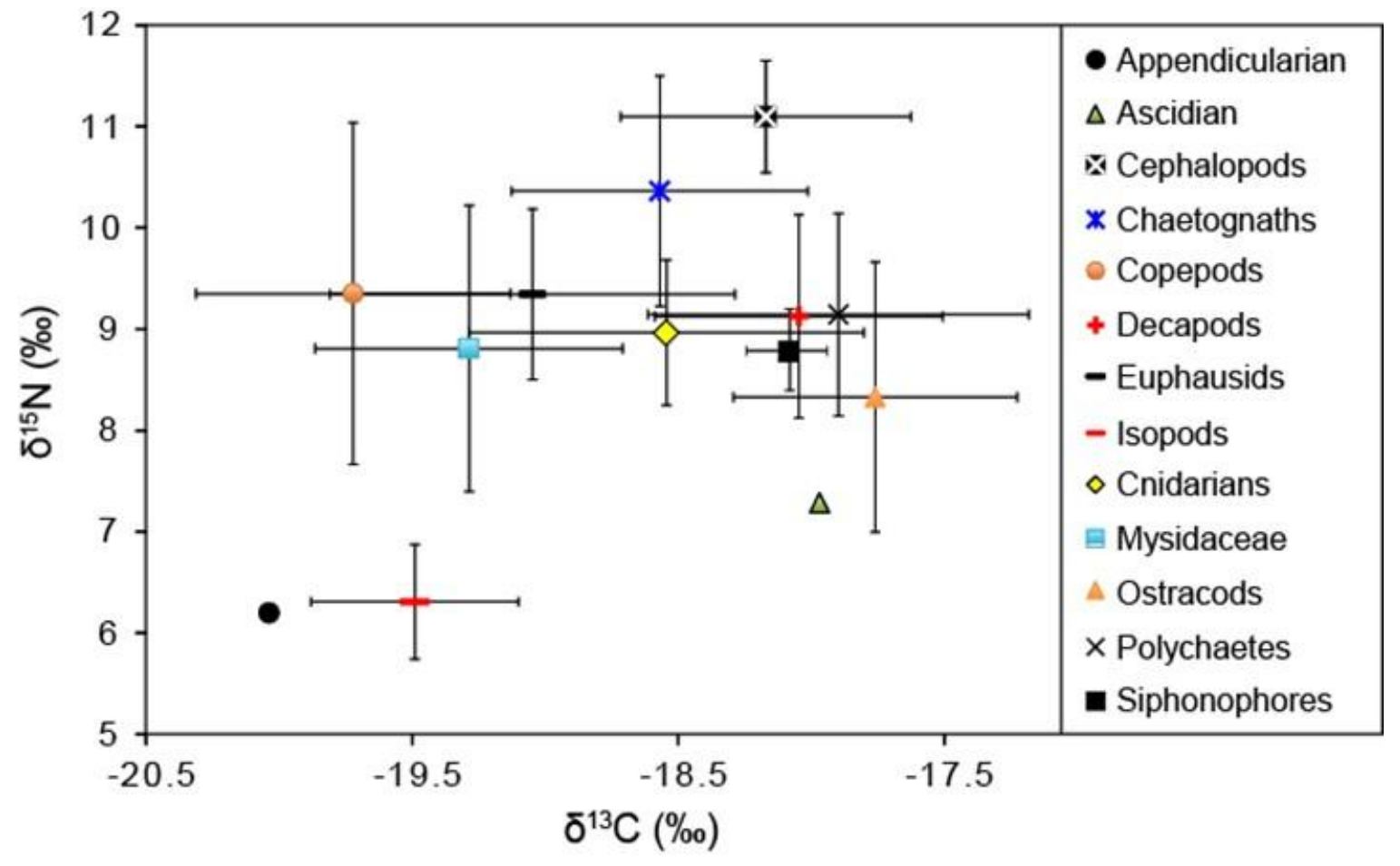

Fig. 7. Plots of the average $\delta^{15} \mathrm{~N}$ and $\delta^{13} \mathrm{C}$ isotope ratio values of mesozooplankton taxa and cephalopods, also showing the mean value of all the copepod taxa in Fig. 6 (bars show S.D.). 


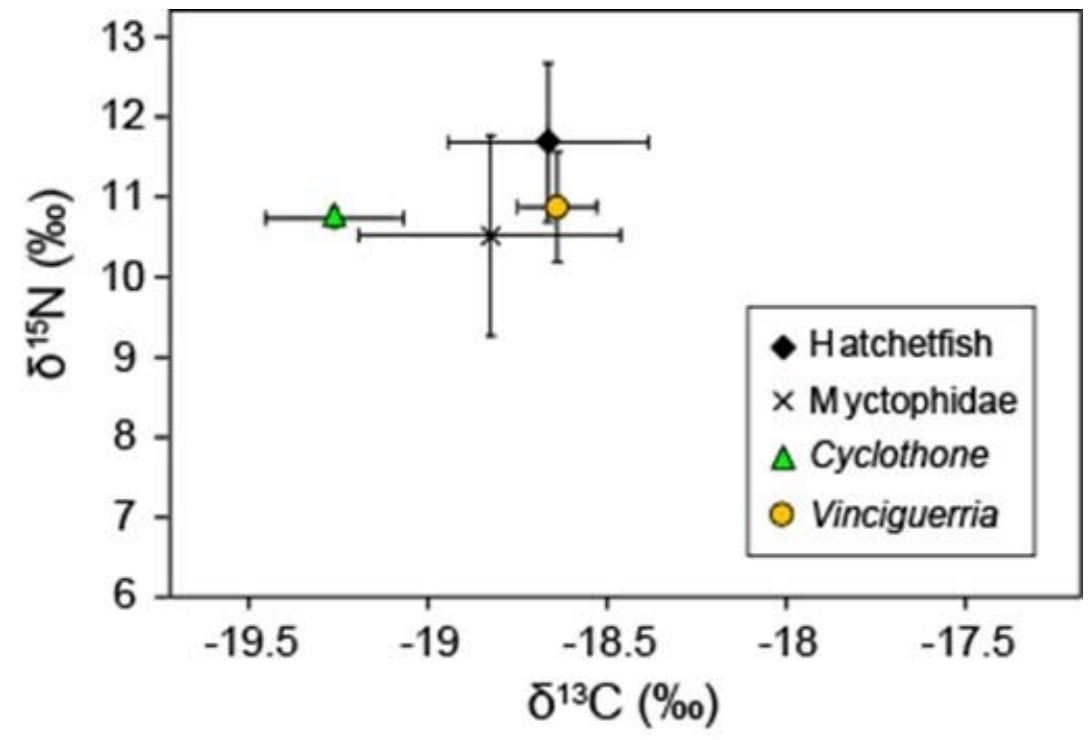

Fig. 8. Plots of the average isotope values of 4 categories of mesopelagic fish (bars show S.D.). 

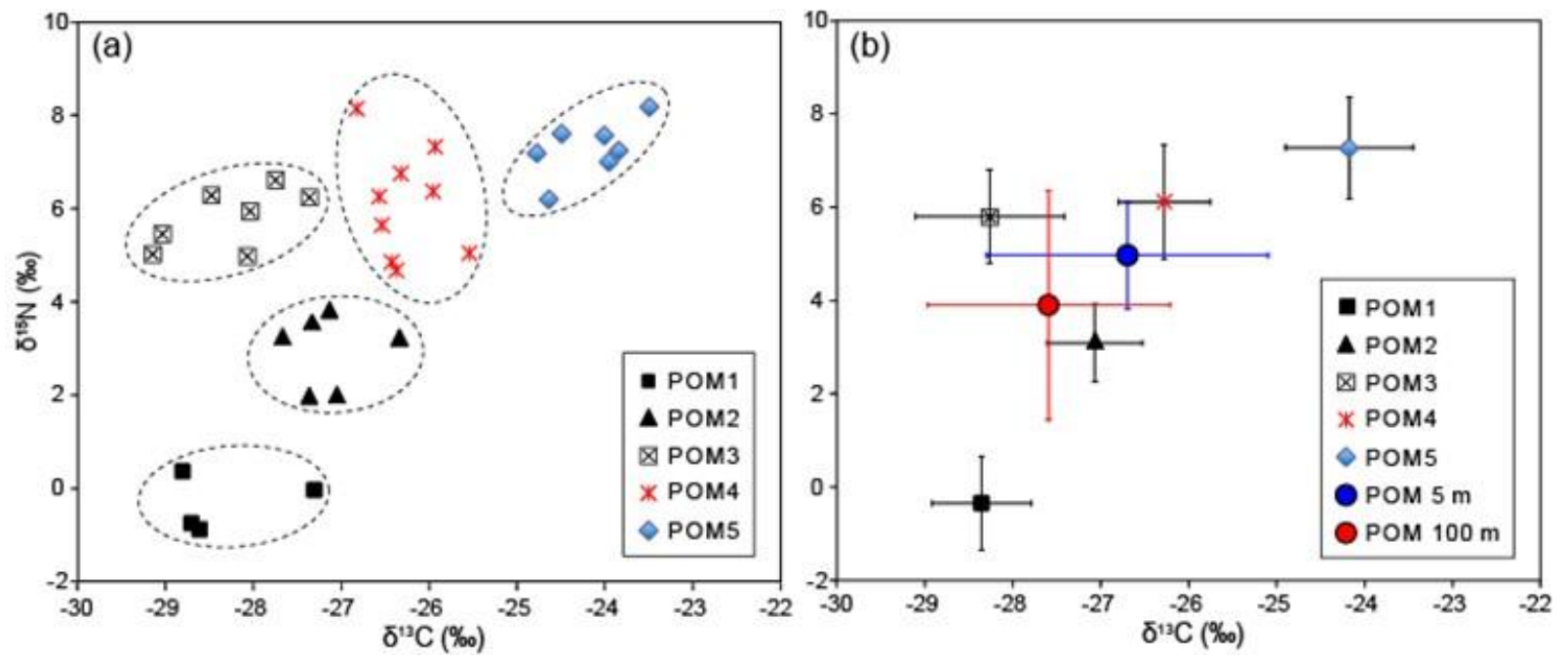

Fig. 9. Plots of $\delta^{15} \mathrm{~N}$ and $\delta^{13} \mathrm{C}$ isotope values of (a) all POM samples that were separated into 5 groups (highlighted by ovals) and (b) the average values of the 5 POM groups found at various stations and POM at $5 \mathrm{~m}$ and $100 \mathrm{~m}$ depths pooled from all stations. 



Fig. 10. Relationship between isotope values of POM collected at $5 \mathrm{~m}$ and $100 \mathrm{~m}$ depths for (a) $\delta^{13} \mathrm{C}$ and (b) $\delta^{15} \mathrm{~N}$. The dashed lines show the positions of 1:1 relationships between the isotopic values at the two depths. 


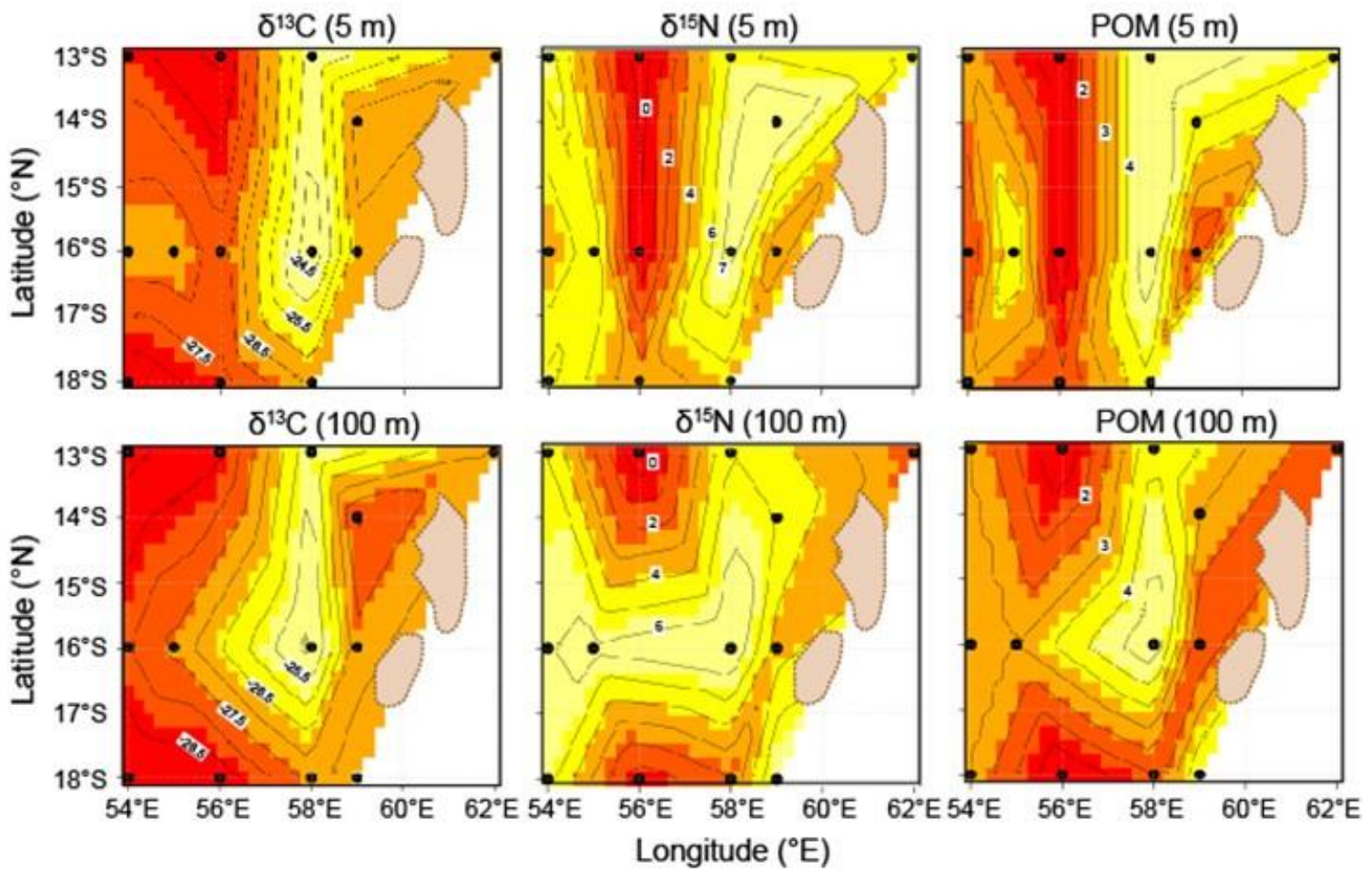

Fig. 11. Contour plots of $\delta^{15} \mathrm{~N}$ and $\delta^{13} \mathrm{C}$ isotope values of POM at $5 \mathrm{~m}$ and $100 \mathrm{~m}$ (left and middle panels) and the average composition of the 5 types of POM (labeled 1-5 in Fig. 9) at the two depths at each station (right panels). Light colors show high values and the dots show the locations of the CTD stations where POM was collected. 


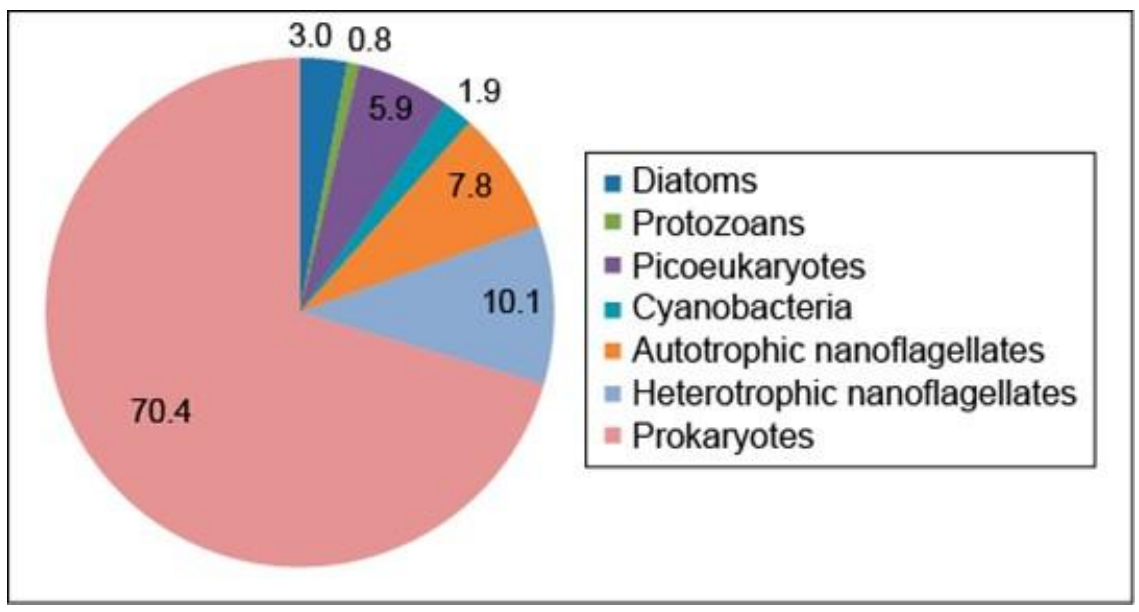

Fig. 12. Relative proportions of the biomass of the major categories of organisms or detritus in POM at all depths combined that were observed by the FlowCam system. 


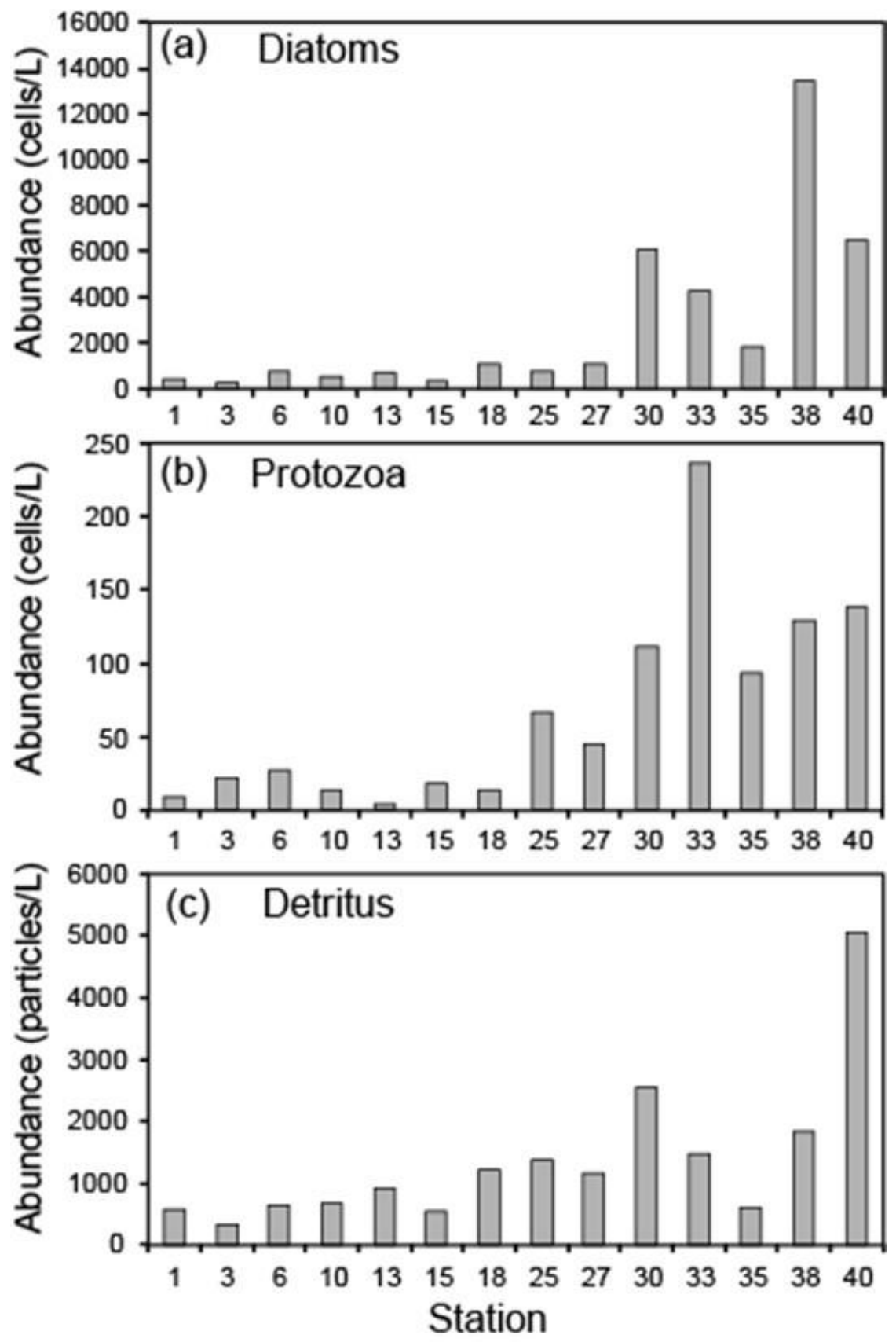

Fig. 13. Abundance of diatoms, protozoans, and detritus in the POM at each station that were enumerated by the FlowCam system. 


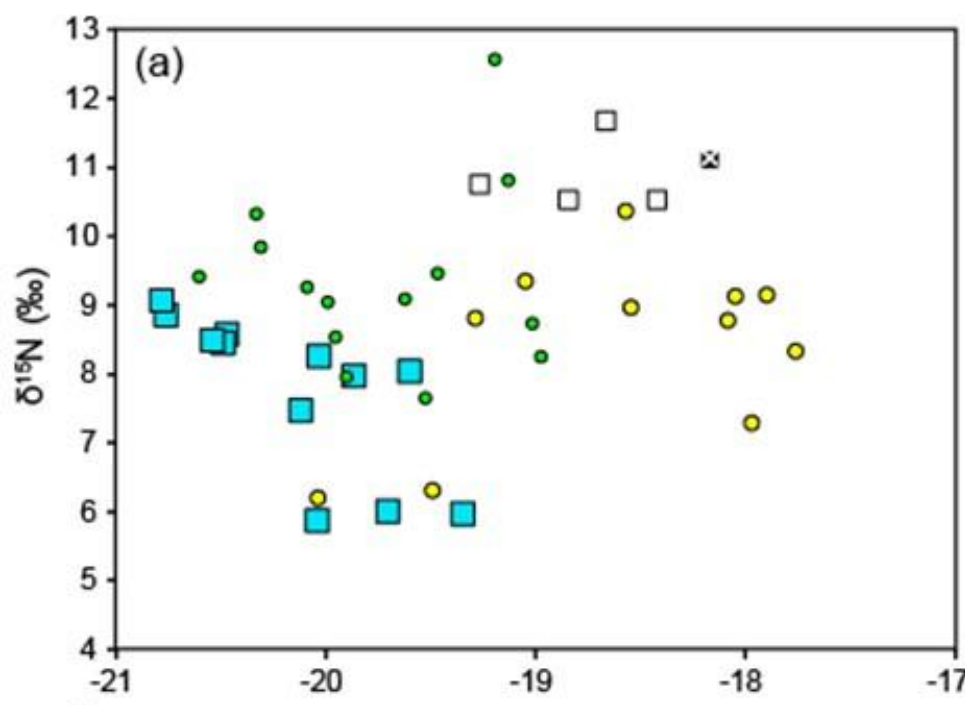

- Copepods o Mesozooplankton ¿ Cephalopods $\square$ Leptocephali $\square$ Fishes

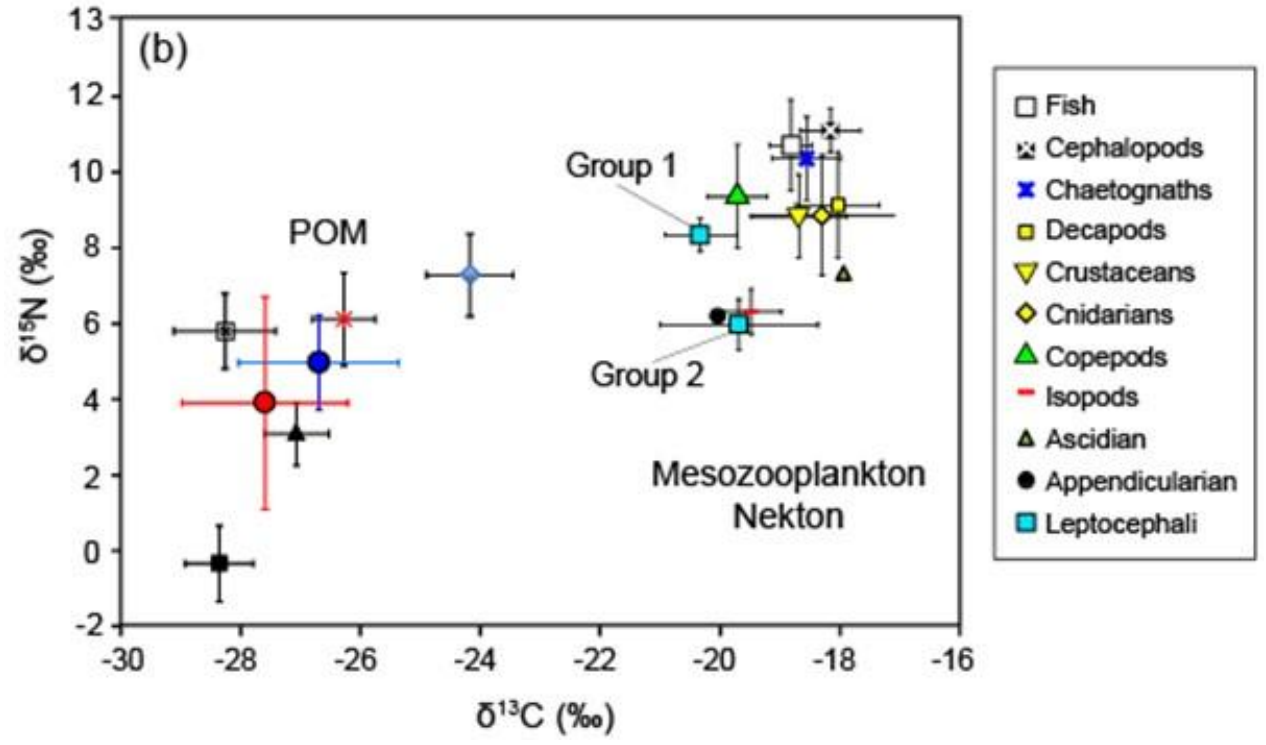

Fig. 14. Plots of average $\delta^{15} \mathrm{~N}$ and $\delta^{13} \mathrm{C}$ isotope values of (a) 12 taxa of leptocephali, copepods, mesozooplankton, cephalopods and fish and (b) of the mean values of the 2 groups of leptocephali and other groups of planktonic/nektonic animals in comparison to POM. 

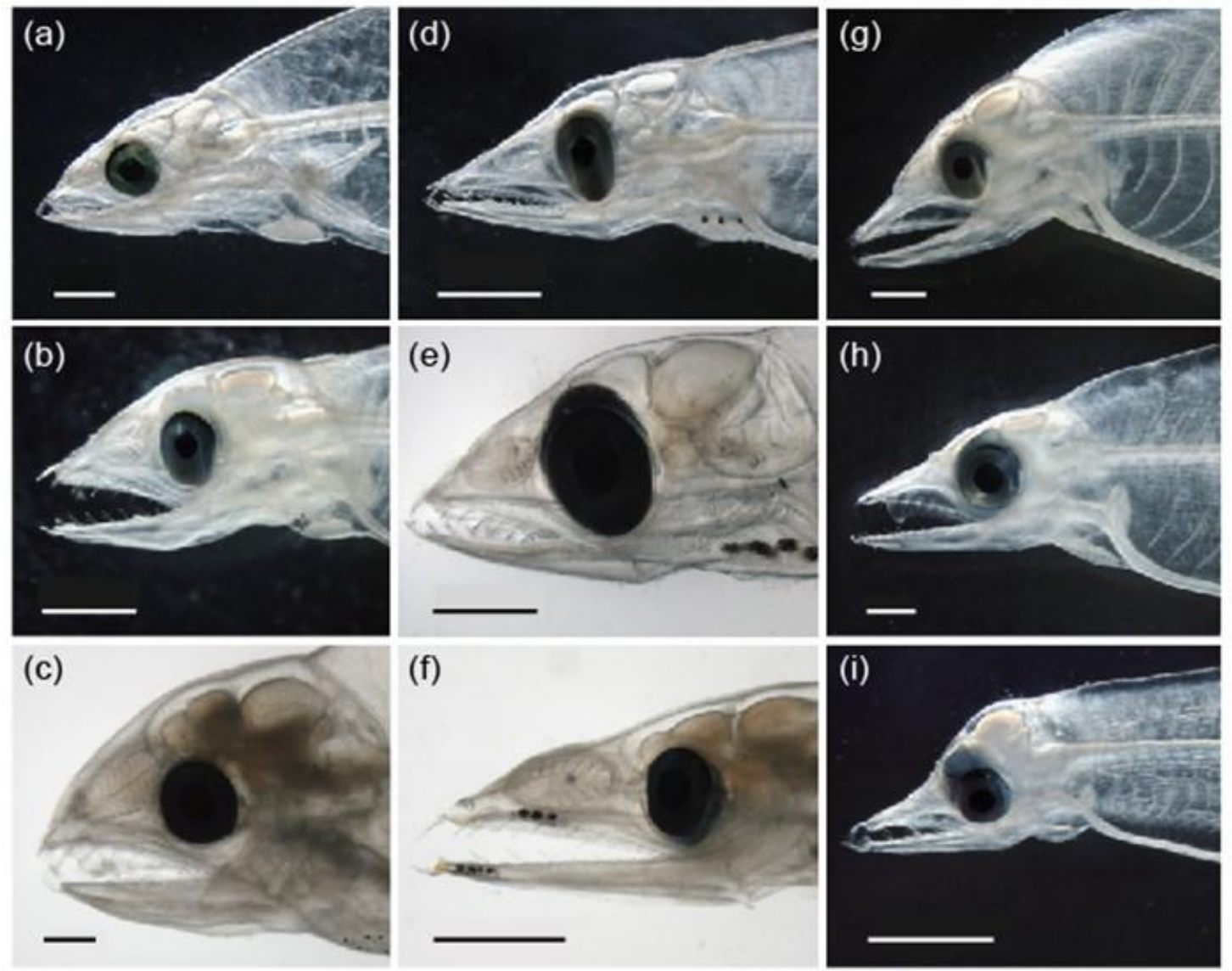

Fig. S1. Head regions of anguilliform leptocephali collected during the KH-09-5 sampling survey showing 9 of the taxa of larvae used for isotopic analyses that are (a) Anguilla bicolor bicolor (54.1 mm), (b) Gorgasia (39.2 mm), (c) Muraenidae (57.4 mm), (d) Gnathophis (38.0 mm), (e) Conger $(68.0 \mathrm{~mm})$, (f) Ophichthidae $(80.3 \mathrm{~mm}),(\mathrm{g})$ Ariosoma-type $(118.0 \mathrm{~mm}),(\mathrm{h})$ Avocettina $(203.3 \mathrm{~mm})$, and (i) Nemichthys (23.7 mm). All specimens shown except (c), (d) and (i) were used for isotopic analysis. Scale bars show $1 \mathrm{~mm}$. 


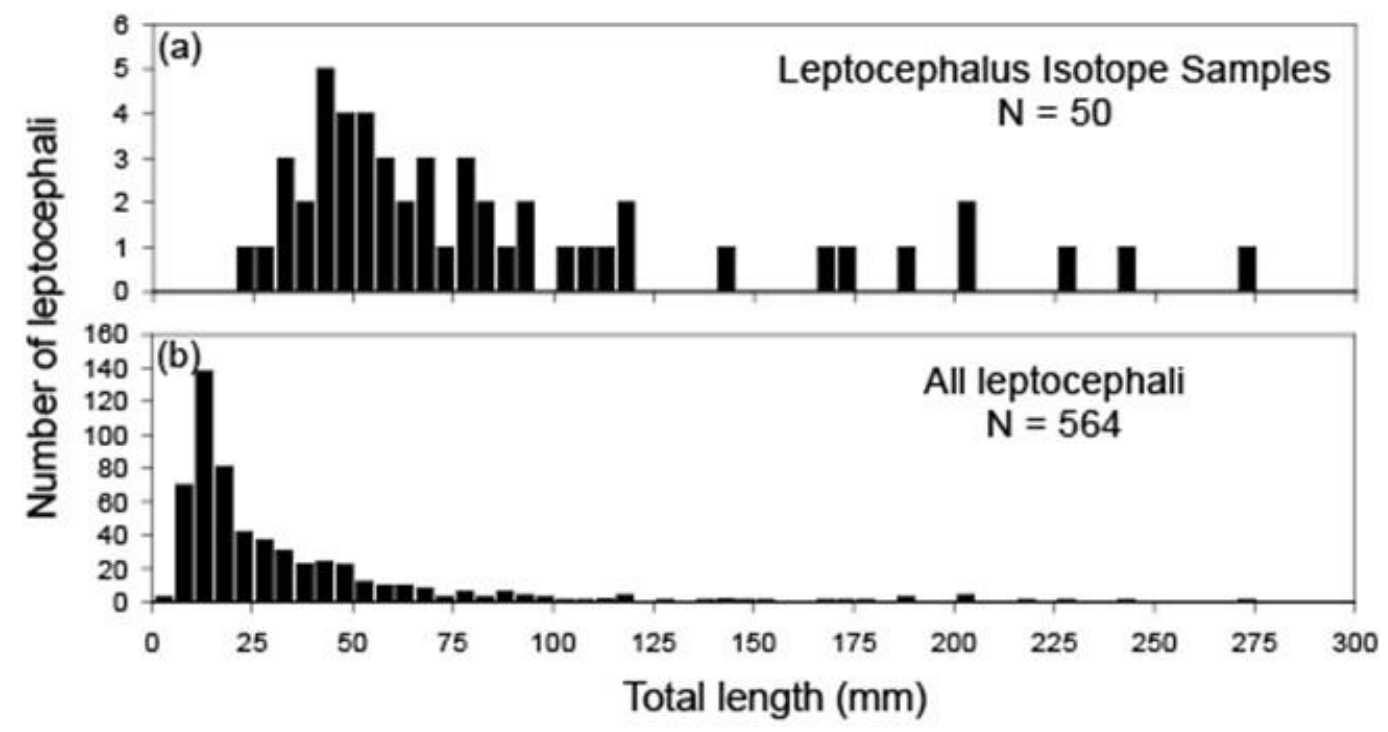

Fig. S2. Length-frequency distribution of (a) the leptocephali used for $\delta^{15} \mathrm{~N}$ and $\delta^{13} \mathrm{C}$ isotope analyses and (b) of all the leptocephali collected during the KH-09-5 survey. 